Article

\title{
Suitability of Totora (Schoenoplectus californicus (C.A. Mey.) Soják) for Its Use in Constructed Wetlands in Areas Polluted with Heavy Metals
}

\author{
Juan A. Blanco \\ Departamento de Ciencias, Universidad Pública de Navarra, 31006 Pamplona, Spain; \\ juan.blanco@unavarra.es; Tel.: +34-948-169859
}

Received: 29 October 2018; Accepted: 15 December 2018; Published: 20 December 2018

\begin{abstract}
Schoenoplectus californicus subsp. tatora (totora) is an endemic plant from wetlands in South America's Altiplano region. In the endorheic Titicaca-Desaguadero-Poopó-Salar de Coipasa system (TDPS), totora can be found along rivers, lakes, and shallow ponds. Lake Uru-Uru is a minor lake placed upstream of Lake Poopó, and it gets water inflows from the Desaguadero River, the city of Oruro and several mining and metallurgic complexes. Polluted waters from these origins, together with natural high salinity and high presence of As and $\mathrm{Pb}$, make Lake Uru-Uru an ideal location to search for plant species suitable to be used in constructed and restored wetlands under pollution stress, particularly in systems with high $\mathrm{pH}$ and salty waters. To test if totora could meet such requirements, healthy plants were collected at two sites in Lake Uru-Uru with different exposure to polluted inflows. Chemical composition of different organs (leaves, rhizomes and roots) were compared. Results indicated totora's capacity to withstand high concentrations of a cocktail of multiple pollutants and heavy metals. Particularly, this research showed totora as a multi-hyperaccumulator (concentrations in shoots higher than $1000 \mathrm{mg} \mathrm{kg}^{-1}$ ) for As, Fe and Ni. These results, combined with totora's intrinsic high rates of biomass production, slow decomposition rates and its value as raw material for local craftwork and industrial uses, support the recommendation to use totora in constructed or restored wetlands, particularly in sites polluted with heavy metals, and in waters with high salinity.
\end{abstract}

Keywords: Totora; hyperaccumulation; heavy metals; Altiplano; Lake Uru-Uru; acid mine drainage; urban wastewater

\section{Introduction}

Wetlands are one of the most productive ecosystems on Earth, usually containing complex trophic webs and high biodiversity. Wetlands also provide important ecological services such as water regulation and recycling, and particularly removal of excessive nutrients, organic matter, and pollutants. Wetlands are also an important source of income for local human populations, directly by providing water, but also indirectly by providing food (game, fisheries, grain, vegetables, etc.), fertility, energy, building materials, and so on. Unfortunately, wetlands are also an ecosystem type that faces some of the highest environmental pressures, ranging from draining to increase land for agriculture, industry, or urban development, to the reduction in water quality and quantity because of human management [1]. The situation is becoming worse as the effects of environmentally unfriendly activities, population increase, and urbanization are combined with a tradition of unsustainable management practices in wetlands [2,3].

In both developed and developing countries, the use of wetlands as disposal areas for untreated wastewater is particularly troublesome. Although wetlands have, in fact, been used as green technology 
to treat various wastewaters for several decades [2,3], such use must be correctly planned to not surpass the ecosystem's capacity to absorb and treat pollutants. Plants used in wetlands constructed for wastewater treatment should, therefore, have the capacity to grow in polluted sites, and even to be harvested as a way to remove pollutants stored in plant biomass. Plants ideal for such purposes should possess an intrinsic capacity to tolerate heavy metals and metalloids, concentrate them in harvestable aerial tissues, have high rates of biomass production, adsorb pollutants on the root surface, develop extensive and deep root systems, have wide distribution ranges allowing growth in many habitats, and should be easy to cultivate and harvest [4].

A particular case of polluted wetlands are those located in endorheic watersheds rich in minerals and with a high concentration of mining sites. Endorheic basins and their associated lakes can be very sensitive to variations in climate and environmentally negative human activities, such as overexploitation or pollution of water resources [5]. One of such cases is the Titicaca-Desaguadero-Poopó-Salar de Coipasa system (TDPS) in South America. The TDPS is situated in the Andes cordillera, at about $14-20^{\circ}$ south latitude and at an average elevation of more than $3500 \mathrm{~m}$ above sea level (m.a.s.l.) It encloses an area of $143,900 \mathrm{~km}^{2}$ in between Peru, Chile and Bolivia. The TDPS is a closed hydrographic basin in which the fresh water Lake Titicaca is connected to the mildly saline Lake Poopó through the Desaguadero River. The overflow of Lake Poopó reaches the hypersaline Coipasa Salt Marsh where evaporation prevents from permanent water levels.

The Poopó basin consists of two lakes: Lake Poopó and Lake Uru-Uru. Lake Uru-Uru is located upstream of Lake Poopó and receives water only from the Desaguadero River, while Lake Poopó receives water from Lake Uru-Uru, as well as from many smaller inflowing rivers. A great number of these streams are rich in dissolved solids due to mining activities as well as natural rock weathering processes [6]. Lake Uru-Uru is, therefore, an antechamber of Lake Poopó. Lake Uru-Uru is also a water body for which scarce information is available, as it has not been included in most of the research done to date in Lake Poopó.

South America's Altiplano is naturally rich in polymetallic deposits [7], being this the reason for the important mining and metallurgical activities established in the region, which play an important role in the local and national economies [8]. The TDPS region hosts important deposits of precious metals (gold, silver) and heavy metals (tin, cobalt, copper, etc.), which have been exploited since before the arrival of European settlers in the 16th century. The exploitation of such resources has traditionally been done at the expenses of water systems, as important water volumes are needed in the mines and metal processing plants. Most of these water flows continue to be returned to the watershed without proper treatment, leading to important issues of metal pollution both in the water bodies and in the surrounding areas at local and regional levels [9].

The shallow lakes and seasonal lagoons typical of the TDPS region are also the habitat of one of the most distinct plants of the Altiplano: the totora (Schoenoplectus californicus subsp. tatora (C.A. Mey.) Soják). Schoenoplectus californicus can be found in coastal and riparian regions from Southern North America [10] to Chile and Argentina [11]. A perennial herbaceous plant, it commonly reaches a height of $4 \mathrm{~m}$, reaching $6 \mathrm{~m}$ occasionally. Totora is a subspecies of the giant bulrush sedge, found in South America in the Lake Titicaca basin, the middle coast of Peru, and on Easter Island in the Pacific Ocean. Totora grows in river and lake shores, at water depths up to $2.5-3 \mathrm{~m}$, but occasionally also at deeper or shallower depths, particularly in areas prone to seasonal flooding. By growing in this extreme habitat, totora shows a great capacity to stand high UV levels, water and temperature fluctuations in an arid tropical tundra climate, with high levels of naturally occurring salt and arsenic [12]. In addition, totora has important economic relevance locally, as a resource for a wide range of applications, from being used as raw material in traditional boat building and basketry to be used in modern architecture and industry [13].

All these features potentially make totora an ideal species to be used either in wetland restoration or in constructed wetlands. Indeed, S. californicus has been reported to be used up to 28 times in constructed wetlands in North America [14]. However, such use has not been reported in the context 
of this species capacity to store different heavy metals. In fact, there is only one available report estimating totora's removal rates of $\mathrm{Zn}$ and $\mathrm{Cu}$ in constructed wetlands $[15,16]$. On the other hand, although some preliminary studies have been done to analyze pollutant levels in totora plants growing in natural wetlands $[6,17]$, a systematic effort to define the concentration ranges of different elements in which this species can grow has not yet been conducted.

Based on my personal observations of the conditions in which totora plants can be found along the TDPS, I hypothesize that totora can stand high levels of pollutants before its growth and survival become impaired. Therefore, the particular objectives of this research were: 1) to provide the most detailed chemical composition of totora organs to date (leaves, rhizomes, and roots) that could be used as a benchmark for future work; and 2) to test if totora is suitable for its use in construction or restoration of polluted wetlands, by testing if it can withstand significant differences in chemical composition in polluted sites compared to non-polluted sites.

\section{Materials and Methods}

\subsection{Research Sites}

Lake Uru-Uru is situated in the lower reaches of the Desaguadero River, before it reaches the Lake Poopó. Lake Uru-Uru is relatively young, as it appeared in 1962 after the Desaguadero River was diverted due to works in a local mining complex. The lake has on average a length of $21 \mathrm{~km}$ and a width of $16 \mathrm{~km}$, with $214 \mathrm{~km}^{2}$ of surface. Its average altitude is 3686 m.a.s.l., the lake bottom is very flat (less than $1 \mathrm{~m}$ of topographical variation in $15 \mathrm{~km}$ ), making the lake very shallow with only $1-2 \mathrm{~m}$ as average water level. This makes the lake very sensitive to seasonal and yearly water level fluctuations. The right arm of the Desaguadero River enters Lake Uru-Uru in its NW shore at Puente Español, close to the city of Oruro, the provincial capital. From Oruro, untreated polluted waters from urban and mining origin enter the lake. The continuation of the Desaguadero River drains Lake Uru-Uru through its southern tip, near the town of Machacamarca, and the overflow continues south through a network of seasonal channels and shallow creeks before reaching Lake Poopó (Figure 1). Climate is tropical xeric and cold. Mean annual precipitation is $332 \mathrm{~mm}$, with precipitation from November to March accounting for $67-85 \%$ of total annual precipitation. The rest of the year is considered the dry season. Mean annual temperature is about $10.6^{\circ} \mathrm{C}$, with maximum temperatures of $23^{\circ} \mathrm{C}$ during the austral summer (November and December) and the lowest $\left(-12^{\circ} \mathrm{C}\right.$ ) in June-July. 


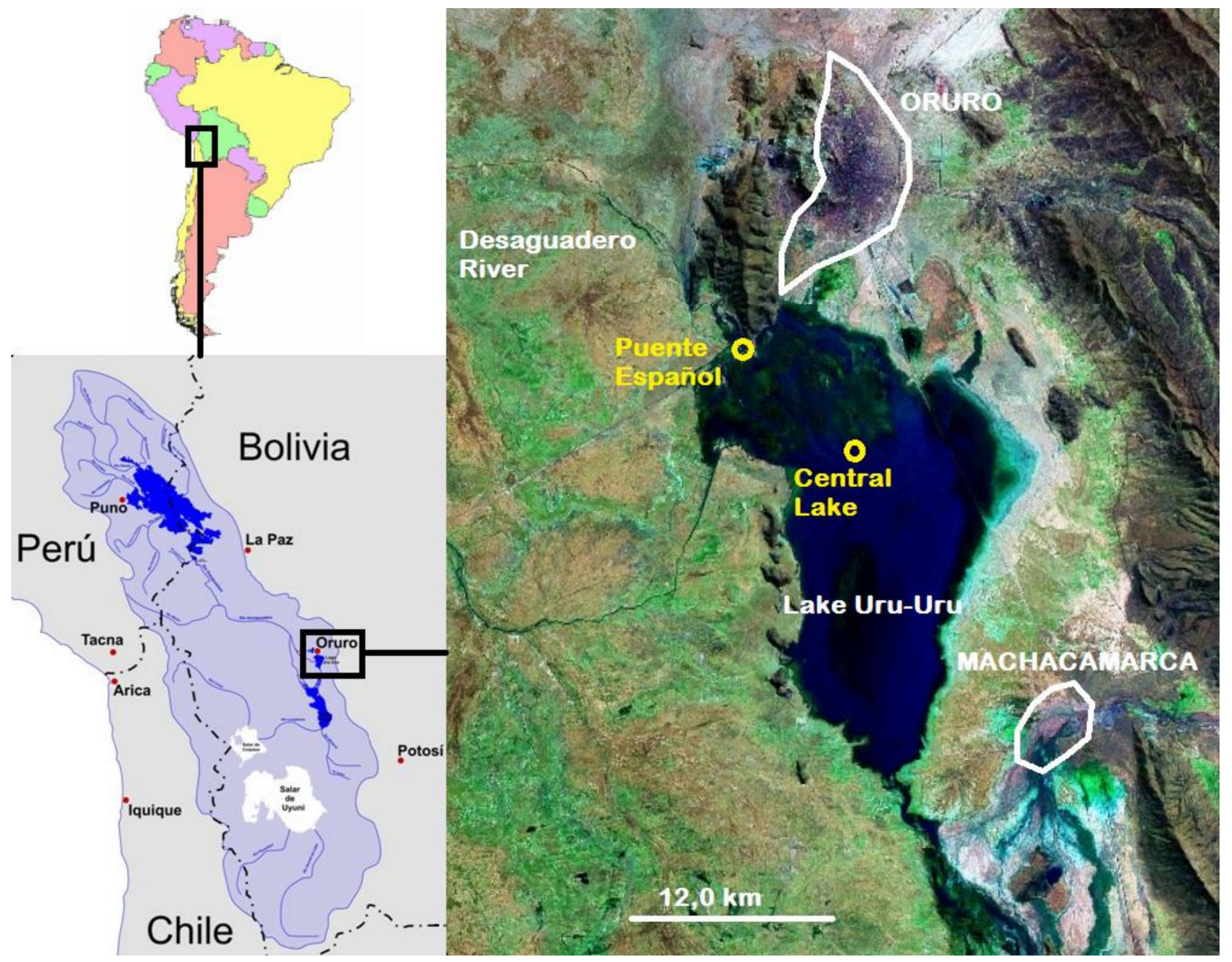

Figure 1. Situation of the endorheic Titicaca-Desaguadero-Poopó-Salar de Coipasa (TDPS) system in South America (left) and the sampling sites in Lake Uru-Uru (yellow circles, right), indicating the population centers of Oruro y Machacamarca (white lines).

Totora samples were collected from two different sites in Lake Uru-Uru. The first site was located beside the Puente Español. This site was considered as the less polluted point in Lake Uru-Uru, as it receives the water from the Desaguadero River and it is above the discharge points of the city of Oruro and the local mining facilities. The second site was located $11.5 \mathrm{~km}$ SE from the first, towards the central portion of the lake. The small creeks bringing effluents from the city of Oruro and acid mine drainage from the surrounding mining facilities had already reached the lake at this point, and, therefore, this was considered as a polluted site. Clear differences in water quality and sediment composition among sites have been reported before (Table 1). At each site, a 100-m long transect was defined parallel to the water shoreline. Twenty plants along each transect were randomly chosen among those that did not display signs of illness, decay or herbivore consumption. Plants were collected by digging them out with a hand shovel to extract the rhizome and most of the main roots. 
Table 1. Chemical characteristics of surface waters and sediments at the two sampling sites. Values averaged from the literature [6,17-22]. A slash indicates that the element is not measured.

\begin{tabular}{|c|c|c|c|c|}
\hline \multirow[t]{2}{*}{ Variable } & \multicolumn{2}{|c|}{ Water (elements in $\mathrm{mg} \mathrm{L}^{-1}$ ) } & \multicolumn{2}{|c|}{ Surface sediments (elements in ppm) } \\
\hline & Puente Español & Central Lake & Puente Español & Central Lake \\
\hline $\mathrm{pH}$ & 8.47 & 8.96 & - & - \\
\hline Conductivity $\left(\mu \mathrm{sm}^{-1}\right)$ & 23.18 & 145.00 & - & - \\
\hline Total suspended solids & 1635.50 & 13530.00 & - & - \\
\hline Total alkali & 133.85 & 146.50 & - & - \\
\hline $\mathrm{CO}_{3}{ }^{2-} / \mathrm{CO}_{2}$ & $26.90 / 0.71$ & $64.97 / 0.69$ & - & - \\
\hline $\mathrm{HCO}_{3}^{-}$ & 116.72 & 129.98 & - & - \\
\hline $\mathrm{Al}$ & 0.03 & 0.01 & - & 63727.47 \\
\hline As & 0.11 & 0.11 & 435.03 & 292.96 \\
\hline $\mathrm{B}$ & 3.08 & 9.82 & - & 115.86 \\
\hline $\mathrm{Be}$ & - & 0.00 & - & 2.06 \\
\hline $\mathrm{Ca}$ & 113.20 & 502.34 & - & 44191.53 \\
\hline $\mathrm{Cl}$ & 679.44 & 8747.17 & - & - \\
\hline $\mathrm{Cd}$ & 0.04 & 0.04 & 0.78 & 1.86 \\
\hline $\mathrm{Co}$ & 0.05 & 0.17 & 6.10 & 8.94 \\
\hline $\mathrm{Cr}$ & 0.00 & 0.01 & 8.15 & 22.34 \\
\hline $\mathrm{Cu}$ & 0.01 & 0.00 & 50.50 & 43.88 \\
\hline $\mathrm{Fe}$ & 0.02 & 0.02 & 15179.40 & 27056.84 \\
\hline K & 20.00 & 101.44 & - & 21266.63 \\
\hline $\mathrm{Li}$ & - & 1.55 & - & - \\
\hline $\mathrm{Mg}$ & 38.16 & 302.86 & - & 9815.80 \\
\hline $\mathrm{Mn}$ & 0.04 & 0.15 & 422.00 & 546.22 \\
\hline Mo & - & 0.01 & - & 2.04 \\
\hline $\mathrm{Na}$ & 408.30 & 2991.42 & - & 12721.53 \\
\hline $\mathrm{Ni}$ & 0.05 & 0.27 & 10.30 & 17.23 \\
\hline $\mathrm{NO}_{3}{ }^{-} / \mathrm{NO}_{2}{ }^{-}$ & $0.32 / 0.03$ & $0.22 / 0.03$ & - & - \\
\hline $\mathrm{P}$ & 0.06 & 0.04 & - & 796.83 \\
\hline $\mathrm{Pb}$ & 0.02 & 0.04 & 56.20 & 58.43 \\
\hline $\mathrm{S}$ & 71.74 & 896.70 & - & - \\
\hline $\mathrm{Sb}$ & 0.05 & 0.08 & 2.00 & 7.81 \\
\hline Se & - & 0.01 & - & - \\
\hline $\mathrm{Sr}$ & - & 3.32 & - & 0.33 \\
\hline $\mathrm{Ti}$ & - & 0.02 & - & 2367.43 \\
\hline $\mathrm{Tl}$ & - & 0.00 & - & 0.82 \\
\hline $\mathrm{V}$ & - & 0.00 & - & 80.35 \\
\hline $\mathrm{Zn}$ & 0.01 & 0.04 & 82.40 & 166.82 \\
\hline
\end{tabular}

\subsection{Chemical Analyses}

Plants were lightly washed with distilled water to remove dirt and dust, and then oven dried at $70{ }^{\circ} \mathrm{C}$ for a week. Then, each plant was divided into different organs (leaves, roots, and rhizomes). Samples were then grounded through a 1-mm sieve (MF-10, IKA). Total N concentration was determined by the dry combustion Dumas method [23] using a TRUSPEC CN628 elemental analyzer (LECO Corporation, MI, USA). Concentration of other elements were measured using inductively-coupled plasma emission spectrometry (ICP-ICAP 6500 DUO Thermo, England), after acid digestion (HNO3-H2O2 4:1) in a microwave.

\subsection{Statistical Analysis}

Transfer factors were calculated as the ratio between the element concentration in each plant organ and the soil. Values above one indicate that plants are enriched in elements compared to their concentrations in soil, ratios around one indicate that plants are not influenced by elements, and ratios below one show that plants exclude the elements from uptake [24]. One-way analyses of equality of means were used to test for significant differences in element composition and transfer factors between 
plants growing in Puente Español and Central Lake. As the assumption of homogeneity of variance among groups was usually violated, the Welch's test was used [25], which is a superior option to other non-parametric tests [26]. To detect relationships among different elements, cross-correlations were carried out. Statistical significance was set at $p<0.05$. All analysis were done with JMP 12.0 (SAS, North Carolina, USA).

\section{Results}

Transfer factors were significantly higher at Central Lake for $\mathrm{As}, \mathrm{Pb}, \mathrm{Fe}, \mathrm{Cu}, \mathrm{Zn}$, and $\mathrm{Cd}$. However, transfer factors of $\mathrm{Mn}, \mathrm{Ni}$ (leaves and roots), and $\mathrm{Cr}$ (leaves) were significantly higher in plants collected at Puente Español. No significant differences among sites in transfer factors were found for $\mathrm{Sb}$ (rhizomes), $\mathrm{Cr}$ (roots and rhizomes), $\mathrm{Co}$ (roots), and Ni (rhizomes) (Table 2).

Table 2. Transfer factors (mean \pm standard error) for different elements in plants collected at Puente Español and Central Lake. Asterisks indicate significantly higher value in the site for concentrations in the same organ, with Welch's tests $(p<0.05)$. A slash indicates element not measured in soil.

\begin{tabular}{|c|c|c|c|c|c|c|}
\hline \multirow[t]{2}{*}{ Element } & \multicolumn{2}{|c|}{ Leaves } & \multicolumn{2}{|c|}{ Roots } & \multicolumn{2}{|c|}{ Rhizomes } \\
\hline & Central Lake & Puente Español & Central Lake & Puente Español & Central Lake & Puente Español \\
\hline \multicolumn{7}{|l|}{ Metaloids } \\
\hline B & $0.85 \pm 0.03$ & - & $0.82 \pm 0.03$ & - & $0.22 \pm 0.01$ & - \\
\hline As & $0.09 \pm 0.01 *$ & $0.01 \pm 0.01$ & $2.95 \pm 0.18^{*}$ & $0.18 \pm 0.01$ & $0.11 \pm 0.01 *$ & $0.02 \pm 0.01$ \\
\hline $\mathrm{Sb}$ & $1.14 \pm 0.04$ & - & $5.94 \pm 0.56$ & - & $1.22 \pm 0.07$ & $0.31 \pm 0.01$ \\
\hline \multicolumn{7}{|l|}{ Alkali } \\
\hline $\mathrm{Na}$ & $<0.01 \pm 0.01$ & - & $<0.01 \pm 0.01$ & - & $<0.01 \pm 0.01$ & - \\
\hline $\mathrm{K}$ & $0.62 \pm 0.02$ & - & $0.40 \pm 0.01$ & - & $0.52 \pm 0.03$ & - \\
\hline \multicolumn{7}{|c|}{ Alkaline earth } \\
\hline $\mathrm{Be}$ & - & - & $0.54 \pm 0.03$ & - & - & - \\
\hline $\mathrm{Mg}$ & $0.04 \pm 0.01$ & - & $0.07 \pm 0.01$ & - & $0.03 \pm 0.01$ & - \\
\hline $\mathrm{Ca}$ & $0.04 \pm 0.01$ & - & $0.05 \pm 0.01$ & - & $0.02 \pm 0.01$ & - \\
\hline $\mathrm{Sr}$ & $85.61 \pm 2.20$ & - & $153.43 \pm 2.53$ & - & $52.27 \pm 1.65$ & - \\
\hline \multicolumn{7}{|l|}{ Semimetals } \\
\hline $\mathrm{Al}$ & $0.01 \pm 0.01$ & - & $0.08 \pm 0.01$ & - & $0.01 \pm 0.01$ & - \\
\hline $\mathrm{Tl}$ & $4.52 \pm 0.25$ & - & $37.04 \pm 3.23$ & - & $6.65 \pm 0.41$ & - \\
\hline $\mathrm{Pb}$ & $0.63 \pm 0.03 *$ & $0.02 \pm 0.01$ & $6.80 \pm 0.35^{*}$ & $0.35 \pm 0.02$ & $0.83 \pm 0.06^{*}$ & $0.07 \pm 0.01$ \\
\hline \multicolumn{7}{|c|}{ Transition metals } \\
\hline $\mathrm{Ti}$ & $0.01 \pm 0.01$ & - & $0.01 \pm 0.01$ & - & $0.01 \pm 0.01$ & - \\
\hline $\mathrm{V}$ & $0.01 \pm 0.01$ & - & $0.09 \pm 0.01$ & - & $0.01 \pm 0.01$ & - \\
\hline $\mathrm{Cr}$ & $0.14 \pm 0.01$ & $0.77 \pm 0.11 *$ & $1.12 \pm 0.06$ & $1.48 \pm 0.19$ & $0.75 \pm 0.22$ & $1.15 \pm 0.17$ \\
\hline $\mathrm{Mn}$ & $0.23 \pm 0.01$ & $3.39 \pm 0.20 *$ & $0.22 \pm 0.01$ & $1.68 \pm 0.01^{*}$ & $0.10 \pm 0.01$ & $0.89 \pm 0.04 *$ \\
\hline $\mathrm{Fe}$ & $0.05 \pm 0.01 *$ & $0.02 \pm 0.01$ & $2.40 \pm 0.15 *$ & $0.47 \pm 0.05$ & $0.19 \pm 0.02 *$ & $0.12 \pm 0.02$ \\
\hline Co & $0.06 \pm 0.01$ & - & $0.26 \pm 0.03$ & $0.19 \pm 0.02$ & $0.08 \pm 0.01$ & - \\
\hline $\mathrm{Ni}$ & $0.18 \pm 0.01$ & $0.28 \pm 0.01^{*}$ & $0.45 \pm 0.02$ & $0.65 \pm 0.07^{*}$ & $0.71 \pm 0.14$ & $0.50 \pm 0.09$ \\
\hline $\mathrm{Cu}$ & $0.28 \pm 0.01 *$ & $0.11 \pm 0.02$ & $3.44 \pm 0.12 *$ & $0.68 \pm 0.03$ & $0.66 \pm 0.03 *$ & $0.30 \pm 0.02$ \\
\hline $\mathrm{Zn}$ & $10.88 \pm 0.39$ * & $0.16 \pm 0.01$ & $52.33 \pm 1.73 *$ & $2.73 \pm 0.10$ & $17.56 \pm 0.71$ * & $0.85 \pm 0.06$ \\
\hline Mo & $0.21 \pm 0.03$ & - & $0.27 \pm 0.03$ & - & $1.02 \pm 0.27$ & - \\
\hline $\mathrm{Cd}$ & $2.43 \pm 0.10$ & - & $73.53 \pm 2.89 *$ & $7.71 \pm 0.78$ & $13.60 \pm 1.68 *$ & $0.37 \pm 0.02$ \\
\hline
\end{tabular}

Significant correlations were found among concentration of different elements, leading to the identification of six different element clusters (Figure 2). The essential macronutrients $C, N$, and $\mathrm{P}$ were grouped together as their concentrations were positively correlated. The smallest cluster was composed by $\mathrm{K}$ and $\mathrm{Mn}$, whose concentrations were also positively correlated. The third cluster encompassed $\mathrm{Mo}, \mathrm{Ni}$, and Se. The fourth cluster was composed mostly by alkali earth elements and light transition metals ( $\mathrm{Ca}, \mathrm{Mg}, \mathrm{Ti}, \mathrm{Al}, \mathrm{V}$, and $\mathrm{Sr}$ ). Their concentrations showed strong positive correlations among them, but also strong negative correlations with the main macronutrients (C, N, and P).

The biggest element cluster was composed mostly by heavier transition metals and semi-metals (As, $\mathrm{Fe}, \mathrm{Cu}, \mathrm{Pb}, \mathrm{Tl}, \mathrm{Cd}, \mathrm{Zn}, \mathrm{Co}, \mathrm{S}, \mathrm{Cr}, \mathrm{Bi}, \mathrm{Sb}$ ), along with As (a metalloid) and $\mathrm{S}$ (a non-metal). Elements in this cluster also showed negative correlations with essential macronutrients ( $\mathrm{N}, \mathrm{P}$, and $\mathrm{K}$ ). The last cluster brought together two alkali ( $\mathrm{Li}$ and $\mathrm{Na}$ ), the lightest metalloid (Be), and the lightest 
alkali earth (Be) element. This last element also shared strong positive correlations with the transition metal/semi-metal cluster (Figure 2).

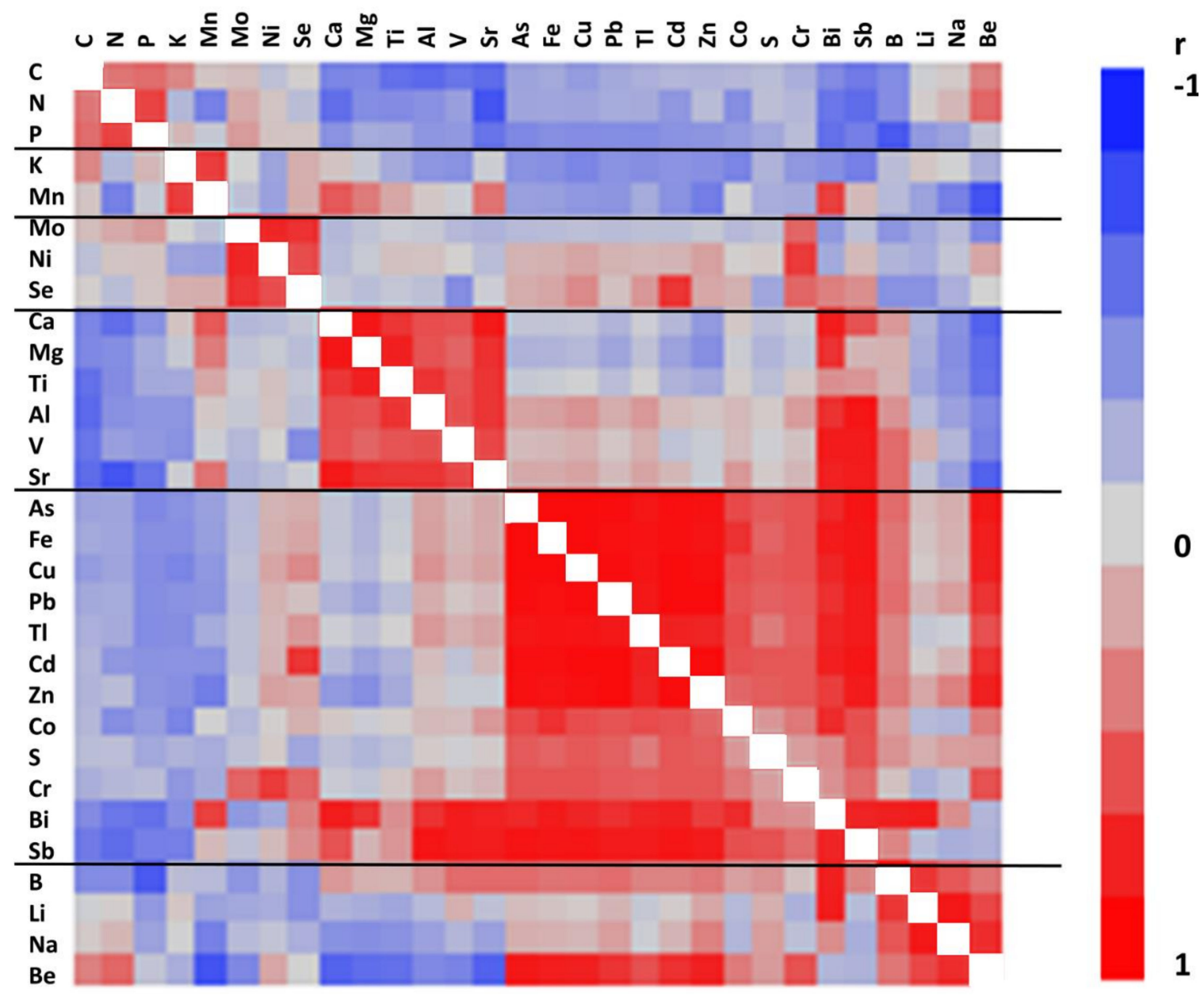

Figure 2. Heat map of Pearson's correlation coefficients among the different element concentrations analyzed.

Regarding differences among sites, for non-metal elements, no significant differences were found for the concentration of $C$ in rhizomes and leaves, neither for $P$ in roots and leaves. $C$ concentration was significantly higher in roots from Central Lake plants, and $\mathrm{P}$ was significantly higher in rhizomes from Puente Español. For the other elements, $\mathrm{N}$ concentrations were higher in roots and leaves from Puente Español, but lower in rhizomes, whereas $S$ showed much higher concentrations in all organs from Central Lake. Se was not detected in roots, but it reached significantly higher concentrations in leaves from Puente Español and in rhizomes from Central Lake (Figure A1).

For metalloids, $\mathrm{Sb}$ was only detected at Central Lake in all plant organs. Arsenic concentration was significantly higher at Central Lake than at Puente Español (from three times more in rhizomes to 14 times more in leaves). B also showed higher concentrations in leaves and roots from Central Lake, but no differences between sites were found for rhizomes (Figure A2).

The alkali metals Li and $\mathrm{Na}$ reached significantly higher concentrations in all plant organs from Central Lake. However, K concentration was significantly higher in leaves from Puente Español, and no differences were found for the other two organs.

For alkaline earth metals, Be was only detected in roots, with significantly higher concentrations at Central Lake. $\mathrm{Mg}, \mathrm{Ca}$, and $\mathrm{Sr}$ showed similar patterns, with significantly higher concentrations of the three elements in all organs collected at Puente Español (Figure A3). 
For semi-metals, Al concentrations were higher in the organs sampled at Puente Español. However, Tl reached significantly higher concentrations in the three organs in plants from Central Lake. The same was true for $\mathrm{Pb}$, which reached much higher concentrations in plants collected at Central Lake than at Puente Español (from 13 times higher in rhizomes to 30 times higher in leaves). Bi was not detected in plants from Puente Español, but it was detected in roots and rhizomes at Central Lake (Figure A4).

Transition metals showed a variety of patterns (Figures A5 and A6). Ti, V, and Mn showed significantly higher concentrations in plants from Puente Español, whereas Fe, $\mathrm{Cu}$, and $\mathrm{Zn}$ reached much higher concentrations in plants from Central Lake. $\mathrm{Cr}$ and Mo showed significantly higher concentrations in leaves from Puente Español, but in roots, $\mathrm{Cr}$ concentration was higher in plants from Central Lake whereas Mo was higher at Puente Español. No significant differences between sites were detected for rhizomes. Co was detected in plants from Puente Español only in roots, where the concentrations were significantly lower than in Central Lake. Ni did not show significant differences among sites for leaves and roots, but its concentration in rhizomes was higher in plants from Central Lake. Cd was not detected in leaves from Puente Español, and its concentration in roots was significantly higher in Central Lake (up to 115 times).

Element distributions in totora organs followed identical patterns at both sites, with six different configurations that could be identified with different strategies to deal with toxic elements (Table 3). Most transition metals, semi-metals and metaloids followed a pattern of clear reduction in their concentrations (exclusion), as the organ was farther away from the pollution source (i.e., the highest concentrations in roots and the lowest in leaves). $\mathrm{Mg}$ concentrations also followed this pattern. The rest of semi-metals and alkali-earth metals, together with $S$, also reached their highest concentrations in roots, but concentrations in leaves were higher than in rhizomes. Two transition metals (Ni and Mo) showed higher concentrations in rhizomes than in roots, but as in the case of other elements of the same group, leaves showed the lowest concentrations. The three main macronutrients (non-metals) reached the highest concentrations in rhizomes and the lowest in roots. Three light elements (Li, $\mathrm{Na}$, and $\mathrm{B}$ ) plus a transition metal (Mn) exhibited the highest concentrations in leaves and the lowest in rhizomes. Finally, $\mathrm{K}$ and Se showed increasing concentrations as the distance from the pollutant source (i.e., sediments) increased (Table 3).

Table 3. Patterns in nutrient concentration along different totora tissues.

\begin{tabular}{|c|c|c|c|}
\hline Concentration pattern & Strategy & Element group & Element \\
\hline Root $>$ Rhizome $>$ Leaf & Excluding micronutrient & $\begin{array}{l}\text { Transition metals } \\
\text { Semi-metals } \\
\text { Alkali-earth metals } \\
\text { Metaloids }\end{array}$ & $\begin{array}{c}\mathrm{Cu}, \mathrm{Zn}, \mathrm{Cd}, \mathrm{Ti}, \mathrm{V}, \mathrm{Cr}, \mathrm{Fe}, \mathrm{Co} \\
\mathrm{Al}, \mathrm{Pb}, \mathrm{Bi} \\
\mathrm{Mg} \\
\mathrm{As}, \mathrm{Sb}\end{array}$ \\
\hline Root $>$ Leaf $>$ Rhizome & $\begin{array}{l}\text { Mobilizing non-labile98 } \\
\text { macronutrient }\end{array}$ & $\begin{array}{l}\text { Semi-metals } \\
\text { Alkali-earth metals } \\
\text { Non-metals }\end{array}$ & $\begin{array}{c}\mathrm{Tl} \\
\mathrm{Ca}, \mathrm{Sr}, \mathrm{Be}^{1} \\
\mathrm{~S}\end{array}$ \\
\hline Rhizome $>$ Root $>$ Leaf & Storing micronutrient & Transition metals & $\mathrm{Ni}, \mathrm{Mo}$ \\
\hline Rhizome $>$ Leaf $>$ Root & Storing macronutrient & Non-metals & $\mathrm{C}, \mathrm{N}, \mathrm{P}$ \\
\hline Leaf $>$ Root $>$ Rhizome & Mobilizing micronutrient & $\begin{array}{l}\text { Transition metals } \\
\text { Alkali metals } \\
\text { Metaloids }\end{array}$ & $\begin{array}{l}\mathrm{Mn} \\
\mathrm{Li}, \mathrm{Na} \\
\mathrm{B}\end{array}$ \\
\hline Leaf $>$ Rhizome $>$ Root & Mobilizing labile macronutrient & $\begin{array}{l}\text { Alkali metals } \\
\text { Non-metals }\end{array}$ & $\begin{array}{l}\text { K } \\
\text { Se }\end{array}$ \\
\hline
\end{tabular}

${ }^{1}$ Be was detected only in roots at both sampling sites. 


\section{Discussion}

Results presented here show totora's remarkable capacity to survive in environments with very high loads of contaminants of different types (metals, salts, alkalis) and from different origin (natural or anthropogenic). Element concentrations in totora organs at Lake Uru-Uru were higher than in other Andean lakes reported before [27,28]. In addition, Se concentrations were similar, but As concentrations were much higher than in S. californicus plants growing in constructed wetlands in South Carolina (USA) [29]. The Puente Español location is considered the least polluted point in Lake Uru-Uru, as it is where the Desaguadero River discharges into the lake. However, the water in the river already contains noticeable levels of salt, metals, and other pollutants, both from natural and anthropogenic origins [21]. The presence of natural high levels of toxic elements, such as As, has been widely reported in the TDPS system, implying that the natural riparian flora should have adapted to this circumstance over the ages. On the other hand, the location of Central Lake is clearly influenced by the discharge from the urban wastewaters from Oruro city, drainage from the abandoned San José's mine (which is still producing acid drainage with low $\mathrm{pH}$ and high content in $\mathrm{S}$ and other metals), and from the active mining and metallurgic operations in the vicinity, such as the Pinto metal smelter.

One way that totora plants have adapted to these potentially toxic levels of several elements is by regulating their movement from the soil to the leaves, the most physiologically important organ in plants. Plants secrete exudates that chelate metals to prevent their uptake inside the cells [30]. Metals can also be bonded in the root cell walls [31]. Such a mechanism could explain the higher transfer factors for metals found in roots, particularly at the Central Lake site, more exposed to pollutants (Tables 2 and 3).

Particularly, totora has shown its capacity to behave as an As hyperaccumulator, with average As concentrations in rhizomes reaching more than $1000 \mathrm{mg} \mathrm{kg}^{-1}$ without visible external signs of vigor loss [32]. The high presence of $\mathrm{P}$ in the soil can reduce As toxicity, as high phosphate concentrations in the cells outcompete As in metabolic reactions [33]. The competition between phosphate and arsenate for binding sites in transporters could also explain the lower $\mathrm{P}$ concentrations found in the plants growing at Central Lake. Similarly, it has been shown that when $S$ is present in high quantities in plants growing in flooded soils, As effects are inhibited [34]. Such behavior could be related to the relationships of $S$ with the synthesis of thiolic compounds, which in turn, are related to As accumulation and metabolism processes. This mechanism could also be working in Lake Uru-Uru, where the high $\mathrm{S}$ loads entering the lake with the acid mine drain could be reducing the negative effects of As from natural and anthropogenic origin. In addition, As bioavailability depends of other minerals, such as $\mathrm{Fe}$ and $\mathrm{Al}$, as well of soil $\mathrm{pH}$. In Lake Uru-Uru, the high $\mathrm{pH}$ and very high $\mathrm{Fe}$ and $\mathrm{Al}$ concentrations in sediments (Table 1) may be having counteracting effects, as high $\mathrm{pH}$ could increase the solubility of certain As forms and, therefore, increase their availability for plants, but at the same time the high levels of $\mathrm{Fe}$ and $\mathrm{Al}$ in the sediments could be sequestering an important portion of As [35]. On the other hand, high As levels are a natural feature of water sources of the TDPS system caused by its particular geology and climate patterns [6]. Therefore, it could be assumed that totora has evolved different traits to deal with high concentrations of this toxic element. Finally, As profoundly affects root growth and metabolism [36]. The lack of visible impacts in the capacity of roots to uptake $\mathrm{P}$ in totora could be an indicator of totora's resistance to As toxic effects, as shown by the lack of significant differences among sites for $\mathrm{P}$ concentrations.

Regarding other metals related to anthropogenic activities, lead is a known factor altering root morphology and $\mathrm{N}$ uptake $[37,38]$. However, $\mathrm{Pb}$ is naturally present in high levels in Lake Uru-Uru [6,18], and water and soils at both sites had similar levels of $\mathrm{Pb}$ (Table 2). Therefore, it is unlikely that this element caused the differences in $\mathrm{N}$ content detected in plant organs. $\mathrm{Cd}$ is one of the most toxic heavy metals because of its high water solubility and easiness to be uptaken by plants. Cd can disrupt $\mathrm{Ca}$ absorption [39] and mimic $\mathrm{Ca}$ activity in the cytosol, producing stomata to close independently of water status [40]. This could partially explain the much higher 
concentrations of $\mathrm{Ca}$ in plants from Puente Español, the less polluted site. Cr competes with $\mathrm{Fe}, \mathrm{S}$, and $\mathrm{P}$ for transporters and carriers. The high levels of Fe and $\mathrm{S}$ in soils and the lack of differences among sites for $\mathrm{P}$ concentrations could indicate some capacity to buffer $\mathrm{Cr}$ toxic effects. Ni may compete with $\mathrm{Ca}$ and $\mathrm{Mg}$, and reduce $\mathrm{P}$ levels in plants [41,42], as well as affect water balance [43]. Ni can also displace $\mathrm{Mg}$ from chlorophyll, reducing photosynthesis efficiency [44,45]. Such behavior could explain the higher Mg levels in plants from Puente Español but, on the other hand, the lack of differences in P concentrations and totora's natural adaptation to high water deficits typical of the TDPS (caused either by aridity of salinity) could be protecting the plants from some of Ni's adverse effects. $\mathrm{Cu}$ alters the photosynthetic capacity of plants, increasing susceptibility to photoinhibition $[46,47]$. However, the adaptation of totora to the high radiation levels reached in the Altiplano (with an average altitude of 3686 m.a.s.l. in Lake Uru-Uru and reaching 3800 m.a.s.l. and above in the Lake Titicaca region) could also reduce its exposition to this negative effect. Fe and Mn toxicity depend on $\mathrm{pH}$ and water logging conditions $[48,49]$. In wetland plants, Fe deposits could be formed in the roots, reducing Fe absorption and constituting a mechanism that could reduce excessive Fe uptake [48]. This process could explain the high Fe levels found in roots from Central Lake. Fe could also cause the low Mn concentrations found in plants from the most polluted site [50]. Antagonism between Fe and other more toxic metals, such as Cd [51], could also have a role in preventing totora from displaying visible signs of toxicity. The lower levels of Mn found in plants growing at the most polluted site could indicate that other elements, such $\mathrm{Pb}$, are impeding roots from absorbing $\mathrm{Mn}$. $\mathrm{Zn}$ toxicity affects root development and can displace $\mathrm{Mg}$ from the photosynthesis apparatus in chloroplasts [52,53]. As $\mathrm{Zn}$ is a typical component of drainage from mines and smelters around Lake Uru-Uru, the very high Zn levels reached in the plants from Central Lake could also combine with the effects of other pollutants to explain the low Mg levels detected in plants from this site.

As for other rare elements, $\mathrm{Tl}$ seems to be antagonist with monovalent alkali [54,55], which are in very high concentrations in Lake Uru-Uru and could have reduced $\mathrm{Tl}$ absorption by roots. Bi has very low solubility and, therefore, it is not considered toxic, although very little information is available [56]. Ti has very low solubility and in moderate concentrations seems to have beneficial effects [57], but its toxicity on plants in high concentrations remains poorly studied. $\mathrm{V}$ has also been reported as detrimental for root growth, although its toxicity seems to be ameliorated by $\mathrm{Ca}$, as they compete for transporters [58]. Mo availability is related to soil $\mathrm{pH}$, but the presence of sulphate can significantly reduce Mo absorption and toxicity [59], a mechanism that may be working in Lake Uru-Uru, given the high levels of $S$ in the sediments. Sr's toxicity in plants is related to its chemical closeness to $\mathrm{Ca}$, being able to supplant this macronutrient [60]. This phenomenon could be related to the lower Ca concentrations found at the more polluted site of Central Lake compared to Puente Español. Finally, Se is easily absorbed by roots interfering with $S$ metabolic processes [32]. Therefore, available sulfates can compete with Se and mitigate its toxicity [61]. Hence, the high S levels in waters from Central Lake (Table 2) could partially offset Se-related toxic effects. However, insoluble elemental Se is more prevalent under anaerobic conditions like the ones in Lake Uru-Uru's sediments, and, consequently, it is reasonable to assume that Se toxicity could be minor.

Mechanism of root-to-shoot transportation of heavy metals involve different compounds that chelate metals. Such compounds could facilitate translocation to vacuoles where heavy metals are then chelated and stored permanently. Chemical differences among elements prevent the use of universal transporters and, therefore, some metals are more easily transported than others are. In addition, chelate compounds vary for different elements [62]. The results shown here indicate that rhizomes play a clear role in the regulation of pollutant transfers in totora plants (Tables 2 and 3), and confirm previous results from constructed wetlands [29]. For most elements, rhizomes acted as a barrier that effectively reduced the amount of metals, semi-metals, and metaloids reaching the leaves. However, such strategy was not enough to keep the levels of all pollutants low in the aboveground biomass. On the other hand, rhizomes could be playing a storage role for the main macronutrients $(\mathrm{C}, \mathrm{N}$, and $\mathrm{P})$, for which other metals such as $\mathrm{Ni}$ and Mo may also 
be benefiting. Similarly, the role of rhizomes as barriers for metals may not be adequate to control light alkalis or metalloids, such as $\mathrm{Li}, \mathrm{Na}$, and $\mathrm{B}$, neither for $\mathrm{Mn}$, as they have high mobility rates. Accumulation of light elements in leaves could indicate the difficulty to prevent them from entering the plant and, therefore, they are displaced to tissues away from roots to avoid physiological damage to the underground tissues [63]. Higher pollutant concentrations in roots than in other tissues suggest that metals transport to the xylem is restricted [64]. The accumulation of some elements in roots could also indicate the use of strategies to prevent the entrance of toxic pollutants into the plant [65]. Totora can also contribute to reductive conditions into the substrate [66], which could translate into more insoluble metal forms [65]. Finally, the highest $\mathrm{K}$ concentration found in leaves is clearly related to the important role of this macronutrient in regulating osmotic pressure, particularly in an arid and hypersaline site such as Lake Uru-Uru.

Element concentrations in totora plants also showed clear associations among them. The three most important macronutrients $(\mathrm{C}, \mathrm{N}, \mathrm{P})$ all showed positive correlations due to their structural and physiological roles in plants. In addition, other nutrients such as $\mathrm{K}$ and $\mathrm{Mn}$ also showed positive correlations as they both are related to osmotic regulation processes. A third group of elements composed by $\mathrm{Mo}, \mathrm{Ni}$, and Se grouped micronutrients that in small concentrations are needed in different enzymatic activities. A fourth group is composed by light elements ( $\mathrm{B}, \mathrm{Li}, \mathrm{Na}, \mathrm{Be})$ all found in salt deposits, typical of endorheic, highly evaporative systems, such as the TDPS [67]. A cluster of elements whose concentrations were positively correlated included macronutrients, such as $\mathrm{Ca}$ and $\mathrm{Mg}$ (both elements scarcely mobile with important structural functions), accompanied by elements such as $\mathrm{V}$ or $\mathrm{Sr}$ that can mimic $\mathrm{Ca}$ and $\mathrm{Mg}$ roles in plants.

The largest elements grouping was composed by the majority of metals and semi-metals. This result could indicate that, rather than being related among them by some physiological function, this group of elements usually appears together in mineral deposits. Around Lake Uru-Uru there are numerous mines and large smelters, currently active, which are an important complex source of $\mathrm{Pb}, \mathrm{Sn}, \mathrm{Sb}, \mathrm{As}, \mathrm{Cd}$, and other elements [8]. These elements are deposited either in the wastewaters or in the discarded material. Mining wastes create a permanent source of pollution that eventually reaches the lake, either through liquid effluents or by wind transport $[8,68-70]$. However, Lake Uru-Uru also has high natural concentrations from natural weathering of minerals with high concentrations of $\mathrm{Pb}$ and As [6,67]. In addition, the Poopó basin in which Lake Uru-Uru is placed hosts several deposits of $\mathrm{Sn}, \mathrm{Bi}, \mathrm{Zn}, \mathrm{Pb}, \mathrm{Cu}$, and $\mathrm{Sb}$, combined with $\mathrm{S}, \mathrm{Ag}$, and $\mathrm{Au}$, exploited by several mining and smelting complexes. These elements eventually reach the lake sediments, and explain the high correlation among them found in the organs of totora plants living in Lake Uru-Uru. Furthermore, the TDPS has several natural salt deposits mixed with clays form the lake sediments, in which high natural concentrations of $\mathrm{Li}, \mathrm{K}, \mathrm{B}, \mathrm{Mg}$, and $\mathrm{Na}$ can be found, and are exploited by different mining companies and local people [6].

Results presented here show totora capacity to accumulate very high concentrations of some pollutants. Under the strictest definition by [71], hyperaccumulator plants are those whose organs can store more than $1000 \mathrm{mg} \mathrm{kg}^{-1}$ of toxic elements in their shoots. Totora plants growing at the Central Lake crossed such threshold for $\mathrm{As}, \mathrm{Fe}$, and $\mathrm{Zn}$ in leaves, making totora a multi-metal hyperaccumulator. Hyperaccumulator plants are mainly endemic to metal-rich soils [72], and they have mechanisms to deal with such toxicity. In addition, totora is adapted to important change in water levels, typical from a shallow system like Lake Uru-Uru, which average depth is only $1.5 \mathrm{~m}$. This feature makes the lake very prone to seasonal and year-to-year severe changes in water level, including the complete lake drying up $[16,73,74]$. S. californicus adaptability to different ecological situations is also supported by its large distribution range, from California to Southern Chile, and from sea level to the Altiplano.

Hyperaccumulator plants usually grow slowly, have limited distribution ranges, or have shallow root systems [4]. However, totora has the opposite traits and, in addition, the capacity to withstand high levels of pollutants, seasonal and periodic changes in water levels, daily swings 
in temperature, and high radiation levels typical from the Altiplano. Moreover, transfer factors in leaves higher than one for $\mathrm{Sb}, \mathrm{Sr}, \mathrm{Tl}, \mathrm{Zn}$, and $\mathrm{Cd}$ indicated totora's high potential for its use in decontamination and phytomining. Previous studies have shown a high capacity of S. californicus to remove contaminants, reaching removal rates up to $80-90 \%$ for $\mathrm{Cu}, 70 \%$ for $\mathrm{Pb}$, or $47-90 \%$ for $\mathrm{Zn}[64,75]$. Aboveground biomass could be harvested, and in fact, totora shoots have been traditionally used for basketry, boat building, and even artificial island building. Nowadays, totora is being suggested as a more formal building material [13]. Such uses would effectively remove the polluted elements from the wetlands and sequester them for long periods in furniture or buildings, although the fate of polluted totora products once their life span has ended should be monitored.

On the other hand, if totora biomass is left on site, part of the pollutants will return to the water as the biomass decomposes. However, totora decomposition rates are low, particularly in polluted sites [76]. In addition, previous studies have highlighted the role of S. californicus not only to absorb and store heavy metals in its biomass [28], but also to provide organic carbon particles to the sediments through the decomposition of dead biomass that can be used as a major carbon and energy source for microbes metabolizing the different heavy metals into sequestered, non-bioavailable and, hence, less toxic forms [15]. Consequently, an important amount of pollutants could be sequestered in totora biomass (both dead and alive). Together, all these features make totora a very attractive plant for its use in constructed wetlands, particularly for saline waters $[4,75,77,78]$, as results presented here show its resistance both to heavy metals and to saline conditions.

\section{Conclusions}

Totora has been identified for the first time as a multi-hyperaccumulator of $\mathrm{As}, \mathrm{Fe}$, and $\mathrm{Zn}$ under the definition by [71]. As the results shown here indicate, totora can survive in environments very harsh for other aquatic plants, including high concentrations of many heavy metals and pollutants and, at the same time, high $\mathrm{pH}$ and salinity. Totora is a riparian, perennial tall plant, in which rhizomes are key to support its capacity to sprout and regrow after losing the aboveground biomass. Rhizomes are also important to control pollutant uptake from contaminated soils. Such resistance to high concentrations of heavy metals, together with totora's intrinsic adaptation to large variations in the environmental conditions (temperature, salinity, water levels, radiation), high growth rates, low decomposition rates, and its value as a raw material for traditional and industrial uses, make this plant species a very valuable choice for its use in constructed wetlands in polluted sites, particularly in saline waters.

Funding: The author was funded by a grant from the Spanish Agency for International Development. Funds for chemical analyses were provided by the Department of Education of the Provincial Government of Navarre, program ANABASI+D. This paper has been published with the support of the Marie Curie Alumni Association.

Acknowledgments: The author thanks Gerardo Zamora Echenique, from the Technical University of Oruro, for his arrangements and support when hosting the author's stay at UTO during the time needed for this research. The author also wants to thank the comments to the original manuscript draft by two anonymous reviewers that helped to improve this paper.

Conflicts of Interest: The author declares no conflict of interest.

\section{Appendix A Appendix}

The following figures provide data on concentrations of chemical elements in different plant organs of plants collected from the two study sites. 
NON-METAL ELEMENTS
C \%
$\mathbf{N} \%$
$\mathbf{P} \%$
$S \mathrm{mg} \mathrm{kg}^{-1}$
Se $\mathrm{mg} \mathrm{kg}^{-1}$
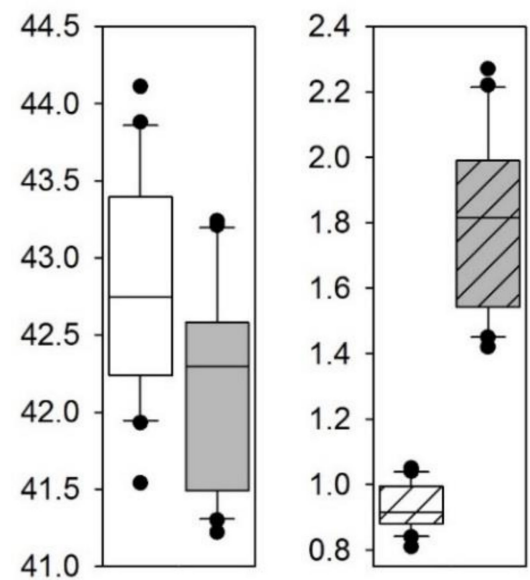

LEAVES
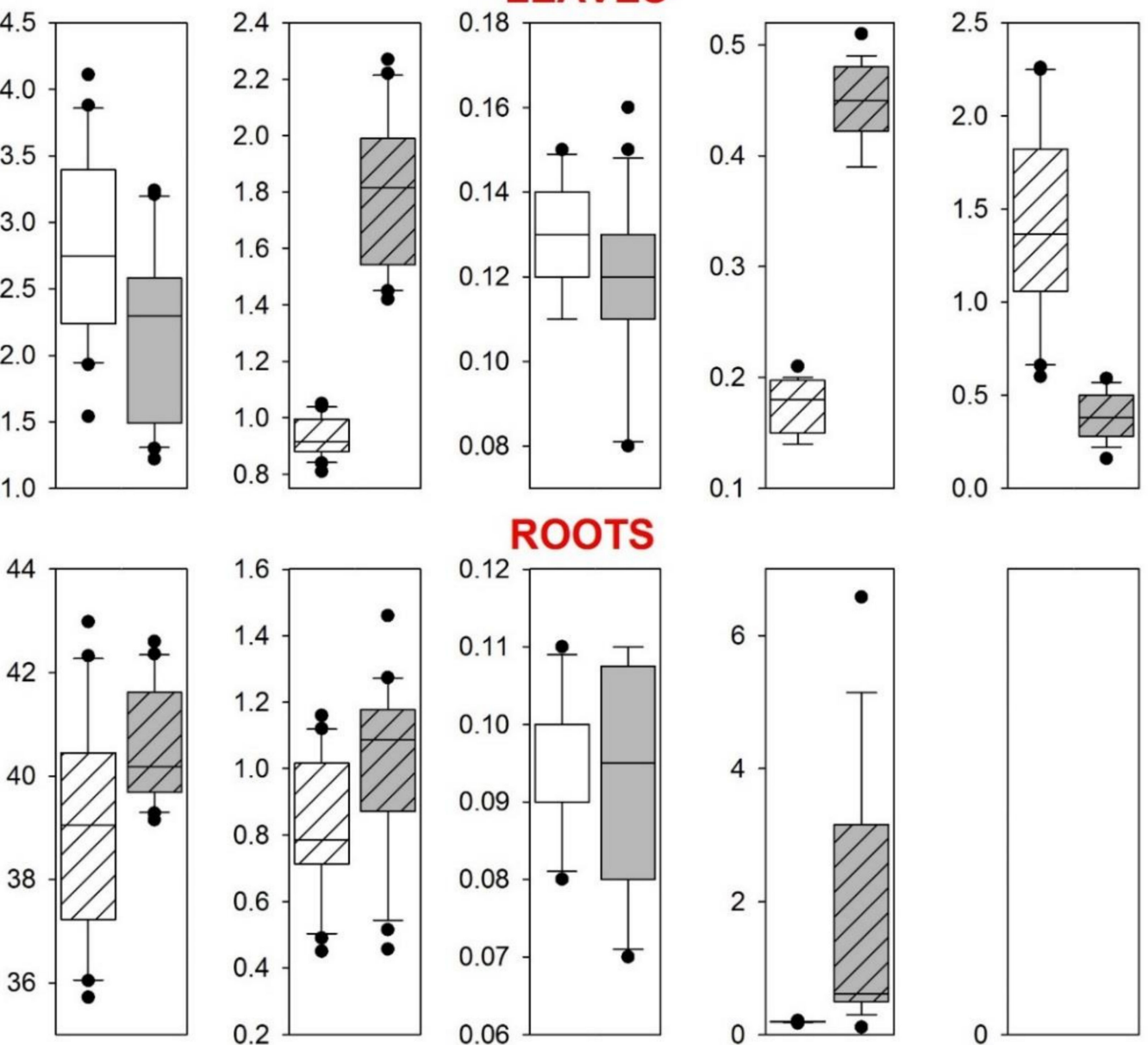

ROOTS
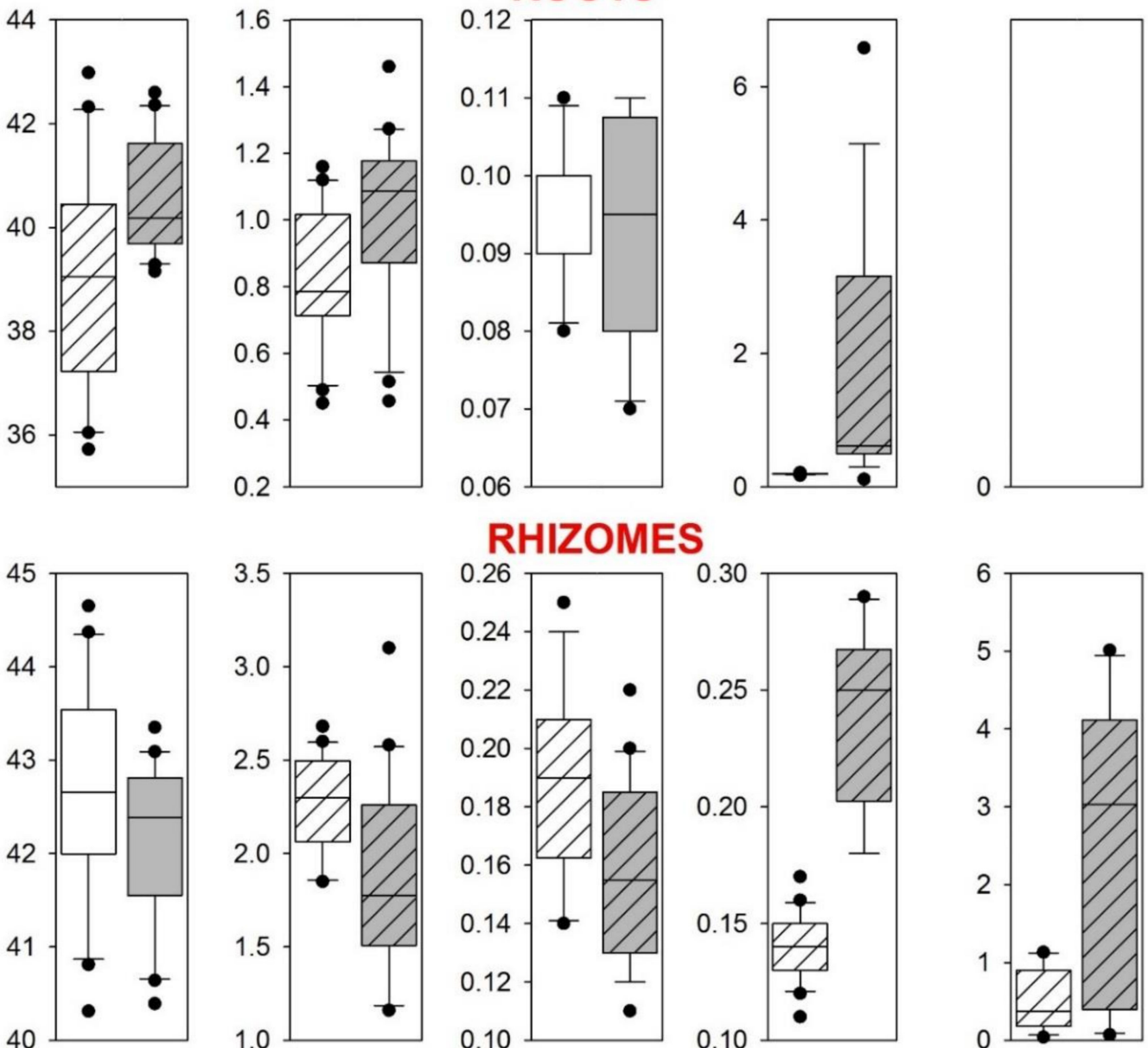

\section{RHIZOMES}
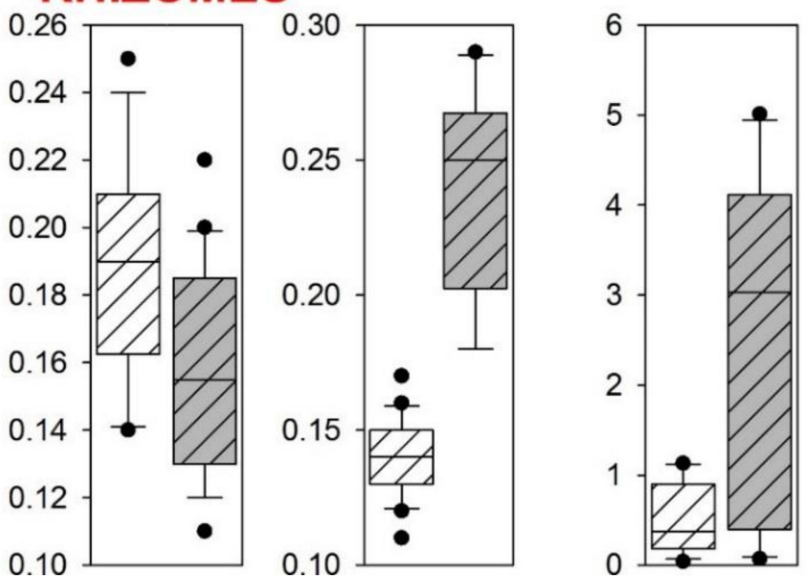

Figure A1. Box-plots of concentrations of non-metal elements (C, N, P, S, Se) in leaves, roots, and rhizomes of totora plants at two different sites: Puente Español (open box) and the lake center (grey box). Stripped boxes indicate significant differences between sites with Welch's test. No traces of Se were found in roots. 
METALOIDS

ALKALI METALS

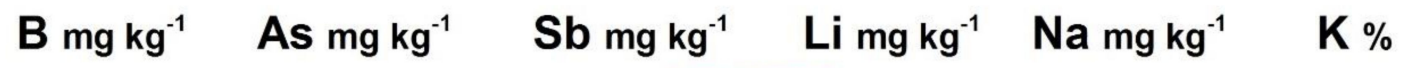
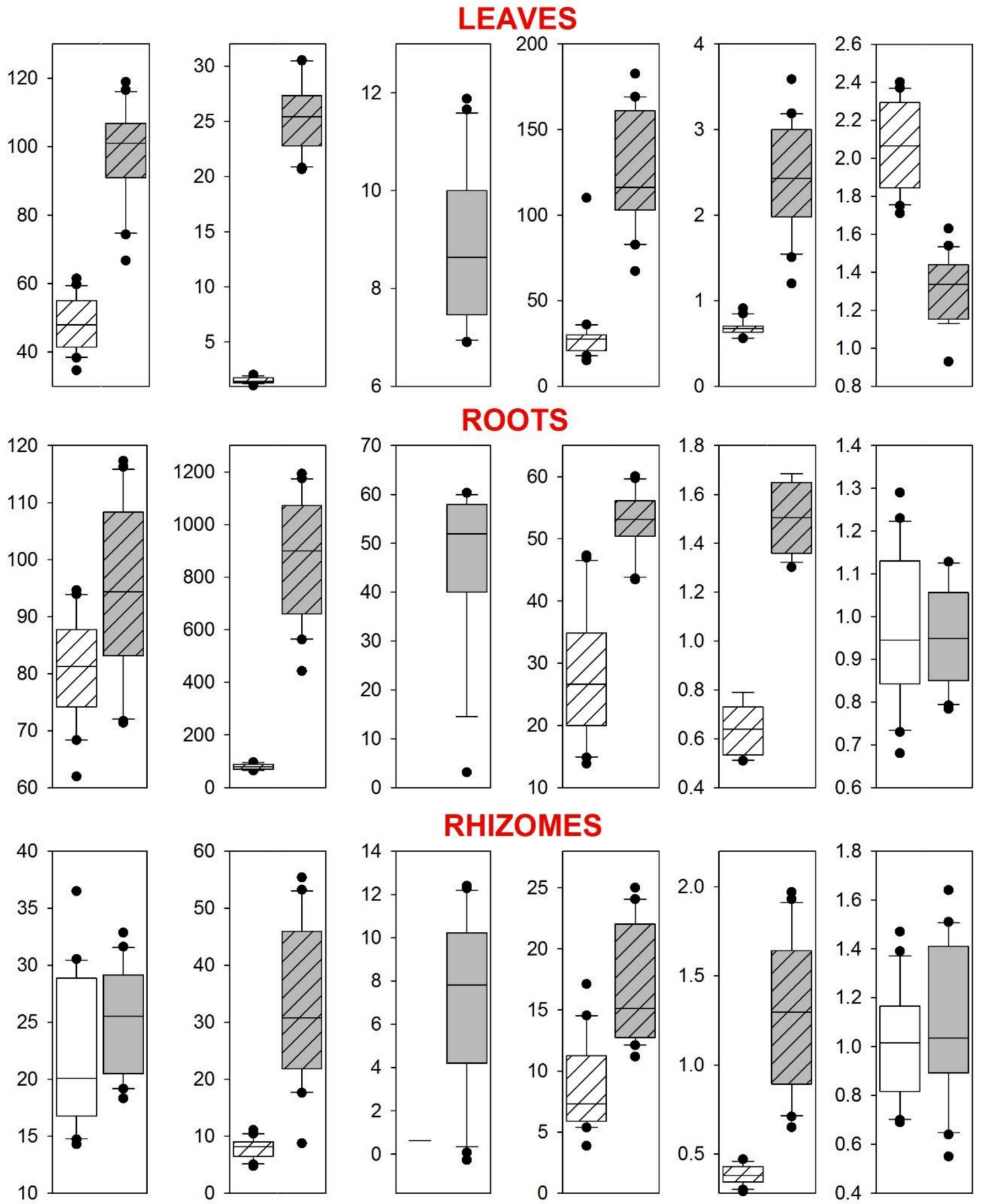

\section{RHIZOMES}
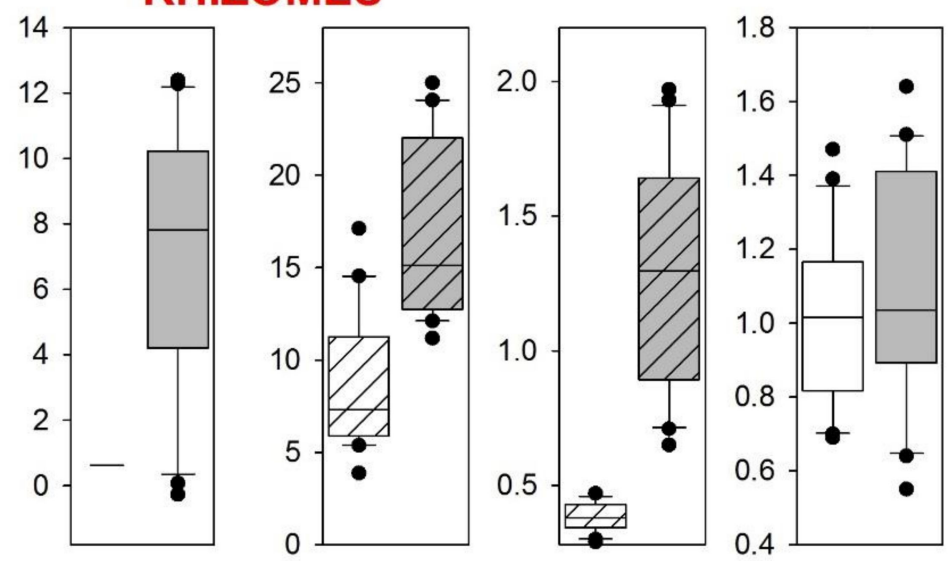

Figure A2. Box plots of concentrations of metaloids (B, As, $\mathrm{Sb}$ ) and alkali metals ( $\mathrm{Li}, \mathrm{Na}, \mathrm{K})$ in leaves, roots, and rhizomes of totora plants at two different sites: Puente Español (open box) and the lake center (grey box). Stripped boxes indicate significant differences between sites with Welch's test. 


\section{ALCALINE EARTH METALS}

$\begin{array}{llll}\mathrm{Be} \mathrm{mg} \mathrm{kg}^{-1} & \mathrm{Mg} \% & \mathrm{Ca} \% & \mathrm{Sr} \mathrm{mg} \mathrm{kg}^{-1}\end{array}$
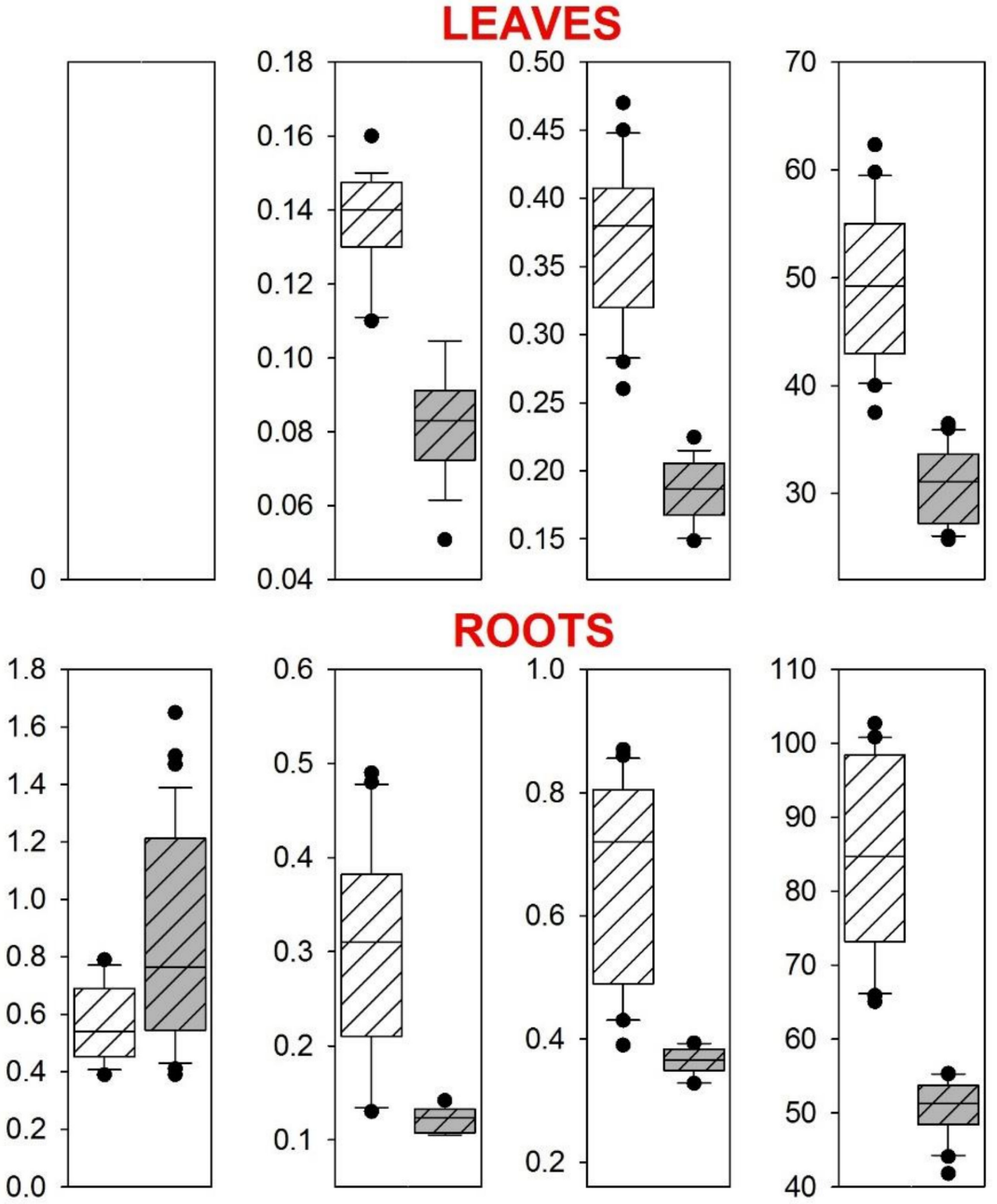

ROOTS
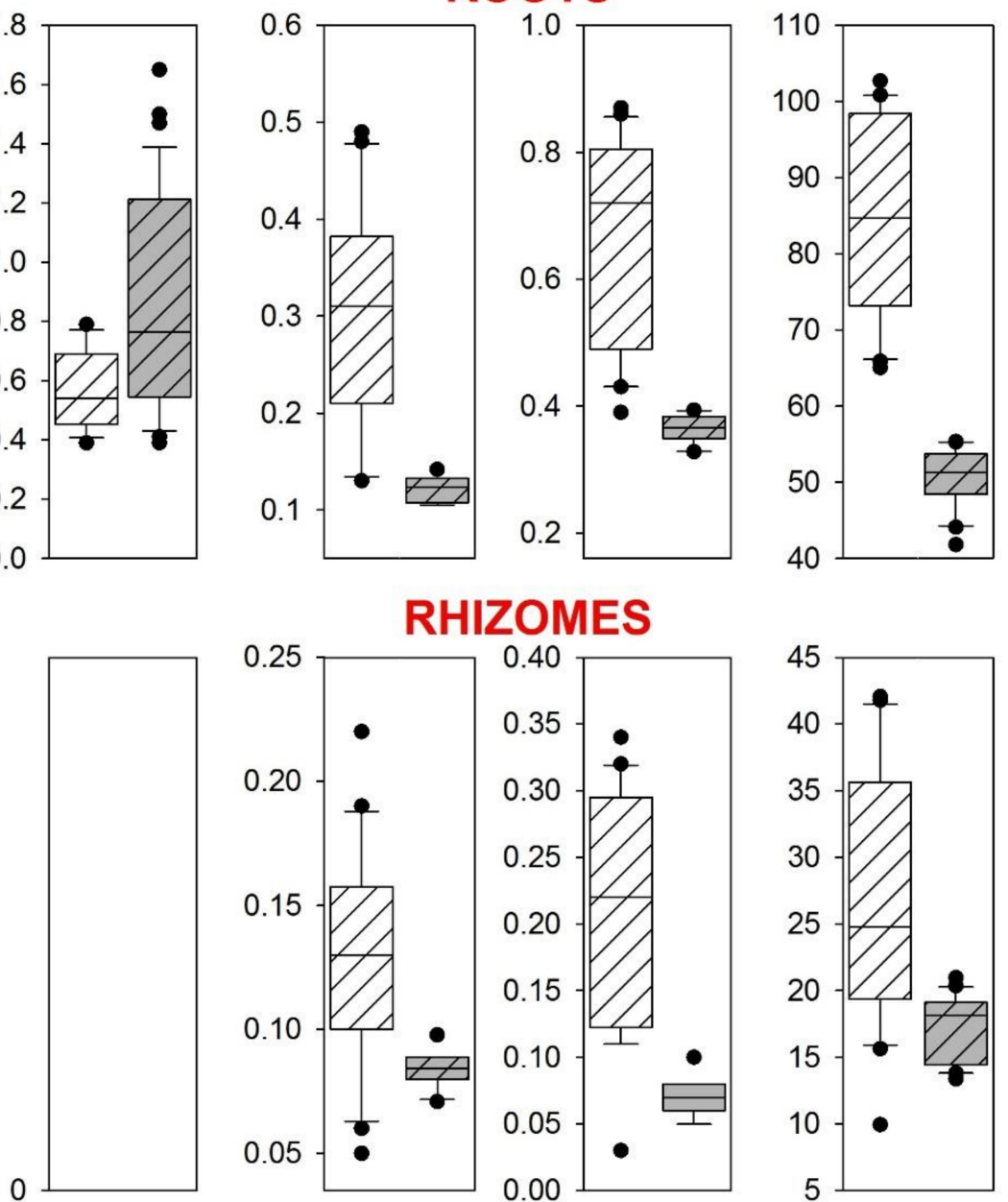

Figure A3. Box plots of concentrations of alkaline earth elements (Be, $\mathrm{Mg}, \mathrm{Ca}, \mathrm{Sr})$ in leaves, roots, and rhizomes of totora plants at two different sites: Puente Español (open box) and the lake center (grey box). Stripped boxes indicate significant differences between sites with Welch's test. No traces of Be were found in leaves and rhizomes. 


\section{SEMI-METALS $\left(\mathrm{mg} \mathrm{kg}^{-1}\right)$}

Al TI $\mathrm{Pb}$

Bi

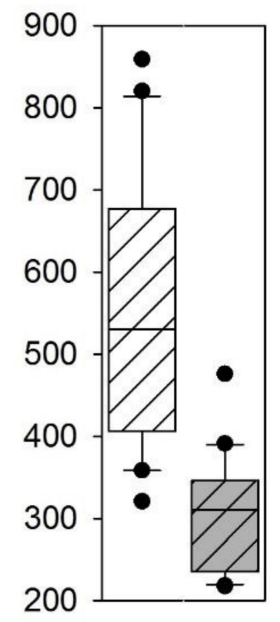

LEAVES
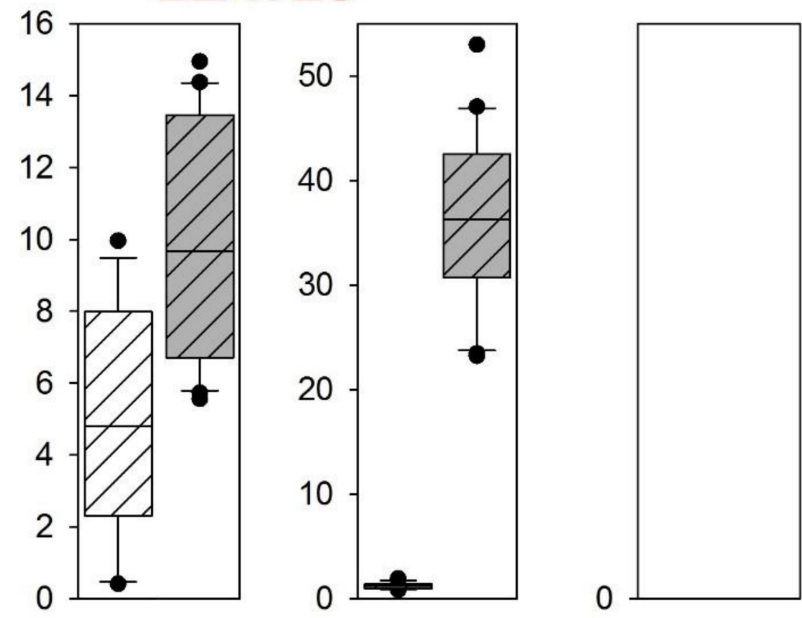

\section{ROOTS}
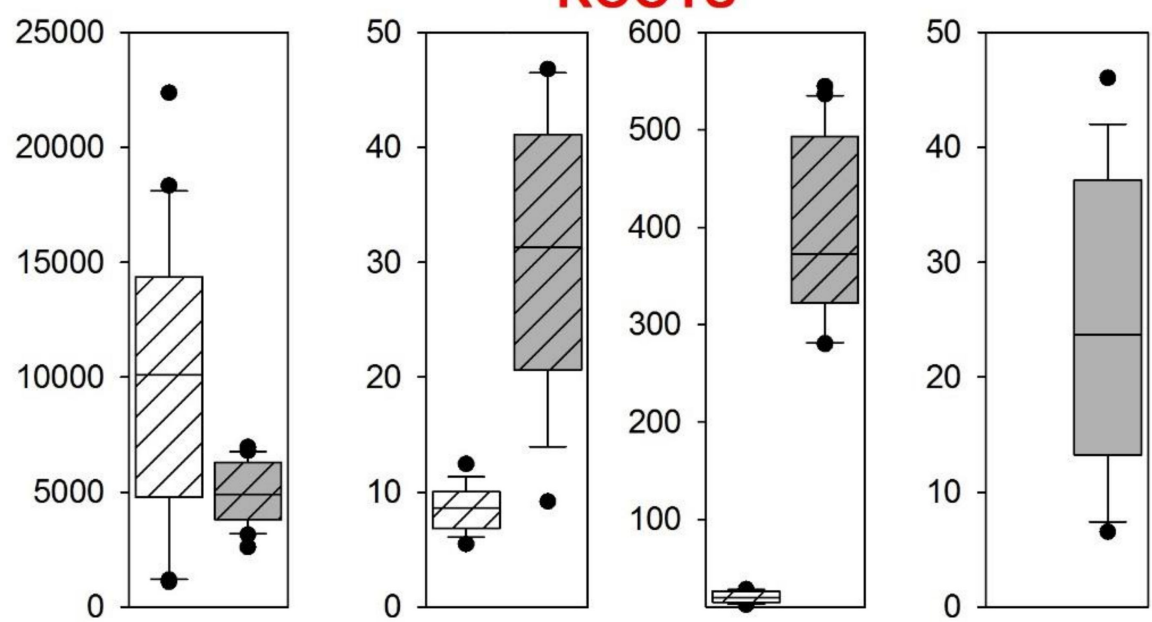

\section{RHIZOMES}
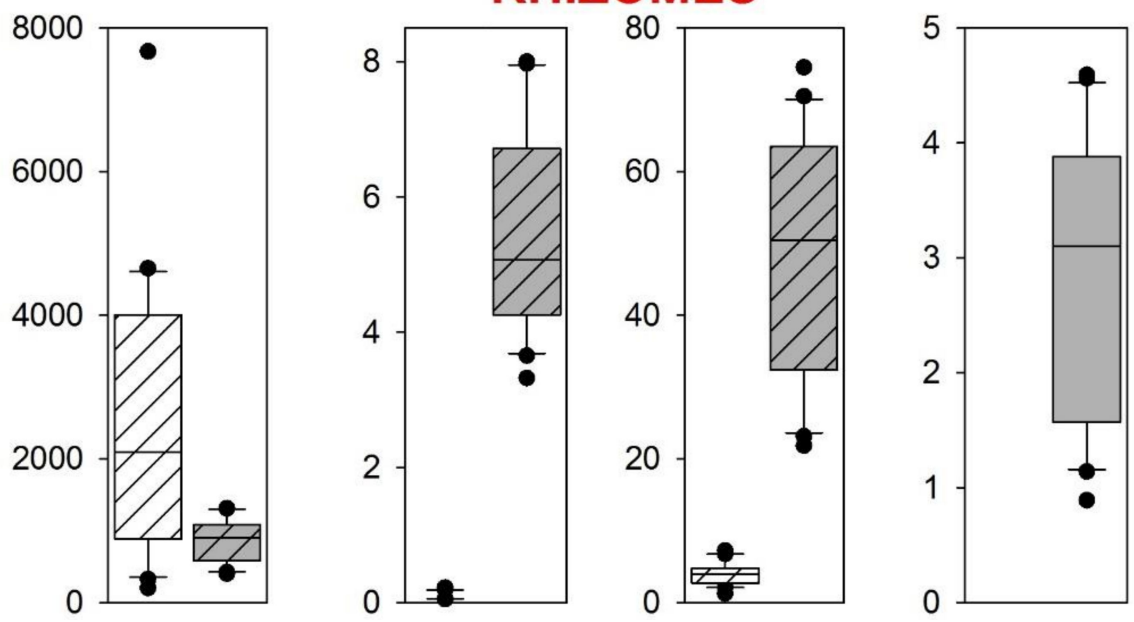

Figure A4. Box plots of concentrations of semi-metal elements ( $\mathrm{Al}, \mathrm{Tl}, \mathrm{Pb}$, and $\mathrm{Bi}$ ) in leaves, roots, and rhizomes of totora plants at two different sites Puente Español (open box) and the lake center (grey box). Stripped boxes indicate significant differences between sites with Welch's test. No traces of Bi were found in leaves. 

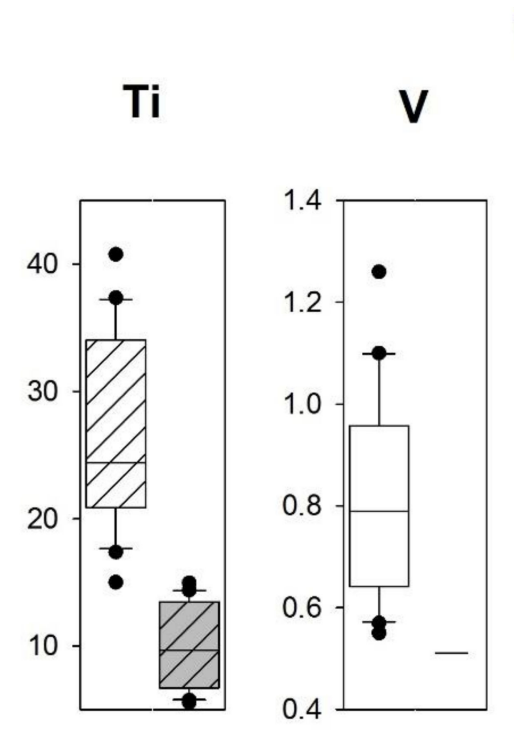

TRANSITION METALS $\left(\mathrm{mg} \mathrm{kg}^{-1}\right)$

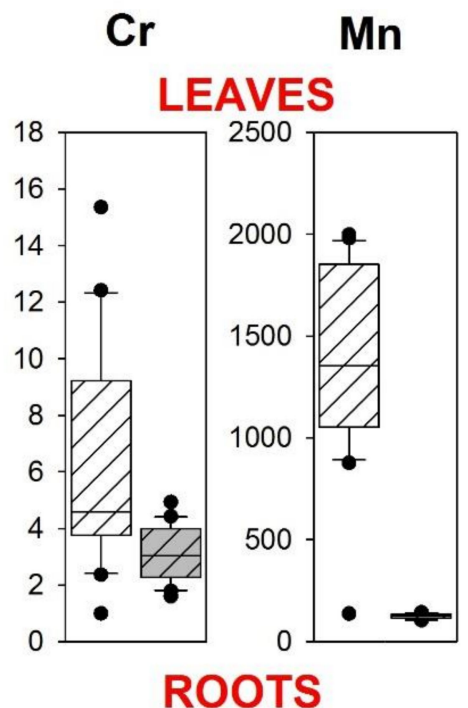

$\mathrm{Fe}$

Co
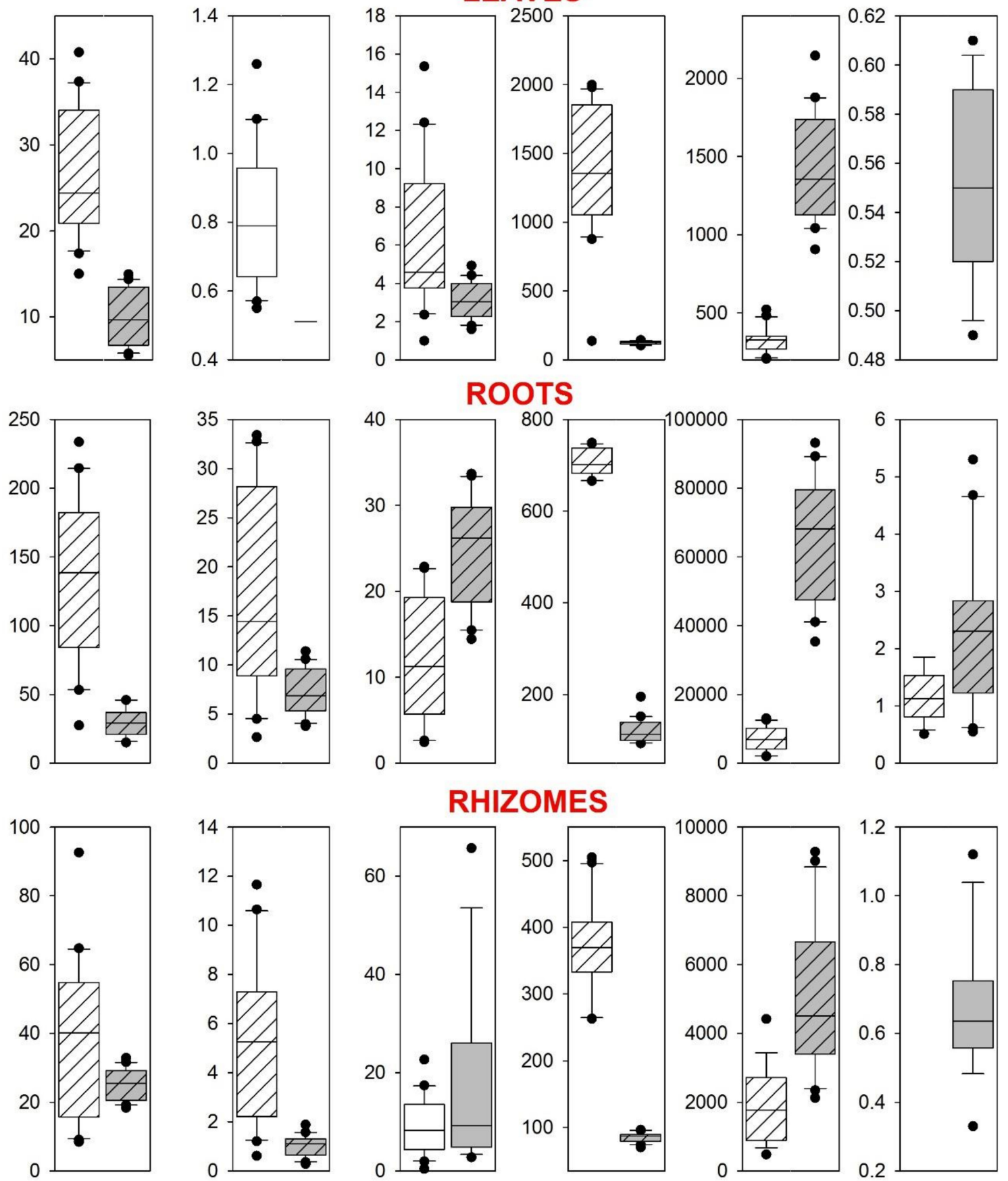

Figure A5. Box plots of concentrations of transition metals ( $\mathrm{Ti}, \mathrm{V}, \mathrm{Mn}, \mathrm{Cr}, \mathrm{Fe}, \mathrm{Co}$ ) in leaves, roots, and rhizomes of totora plants at two different sites: Puente Español (open box) and the lake center (grey box). Stripped boxes indicate significant differences between sites with Welch's test. 
TRANSITION METALS (cont.) ( $\mathrm{g} \mathrm{k} \mathrm{k}^{-1}$ )

$\mathrm{Ni}$

$\mathrm{Cu}$

$\mathrm{Zn}$

Mo

Cd

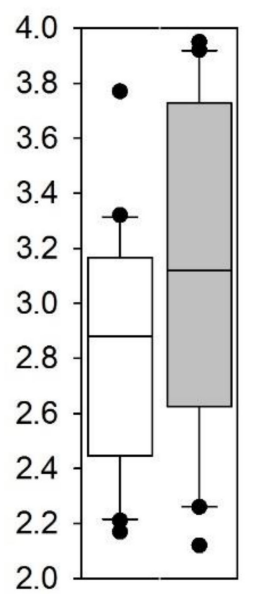

LEAVES
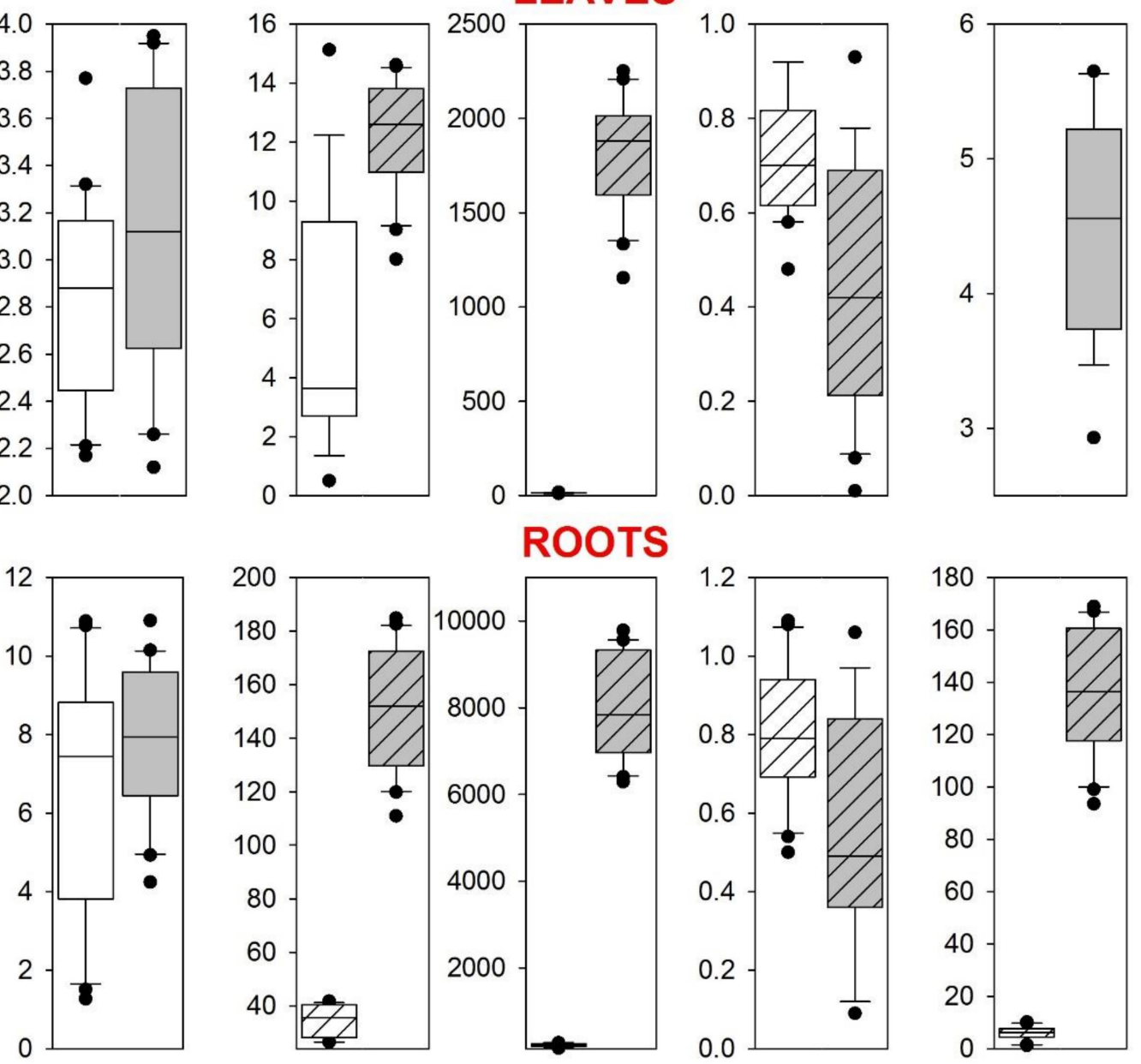

RHIZOMES
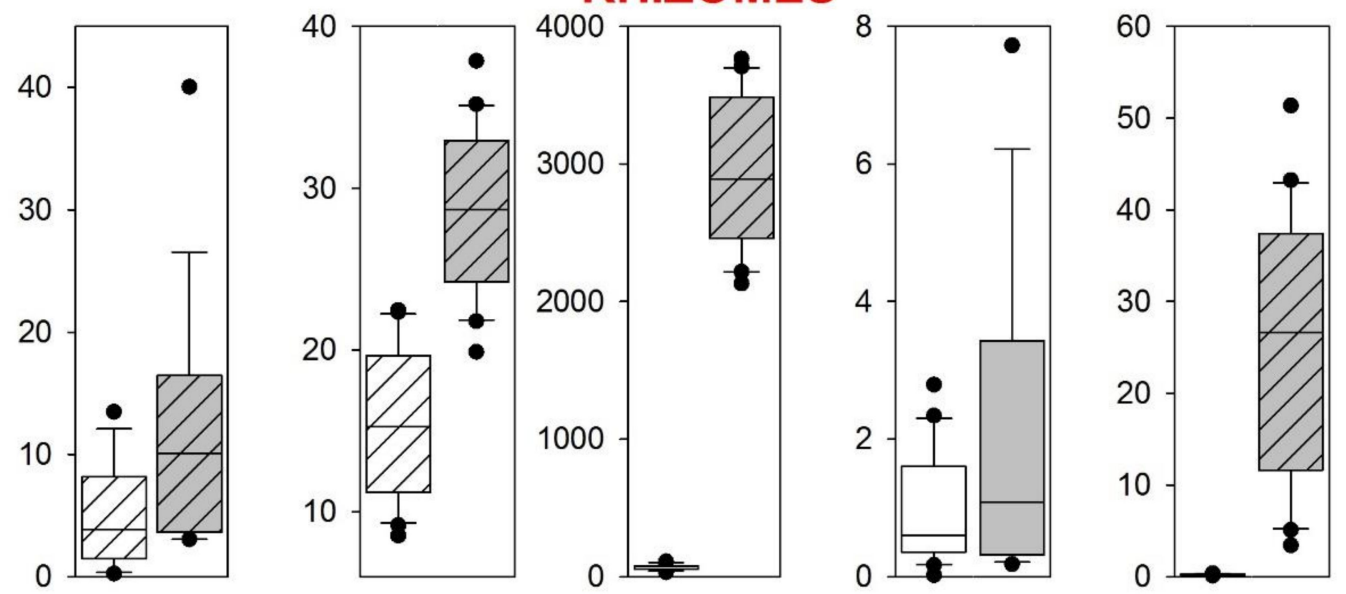

Figure A6. Box plots of concentrations of transition metals $(\mathrm{Ni}, \mathrm{Cu}, \mathrm{Zn}, \mathrm{Mb}, \mathrm{Cd})$ in leaves, roots, and rhizomes of totora plants at two different sites: Puente Español (open box) and the lake center (grey box). Stripped boxes indicate significant differences between sites with Welch's test. 


\section{References}

1. Whigham, D.F. Ecological issues related to wetland preservation, restoration, creation and assessment. Sci. Total Environ. 1999, 240, 1-3. [CrossRef]

2. Vyrmazal, J. Constructed wetlands for wastewater treatment: Five decades of experience. Environ. Sci. Technol. 2011, 51, 165-171. [CrossRef]

3. Wu, H.; Zhang, J.; Ngo, H.H.; Guo, W.; Hu, Z.; Liang, S.; Fan, J.; Liu, H. A review on the sustainability of constructed wetlands for wastewater treatment: Design and operation. Biosour. Technol. 2015, 175, 594-601. [CrossRef] [PubMed]

4. Nesler, A.; Furini, A. Phytoremediation: The utilization of plants to reclaim polluted sites. In Plants and Heavy Metals; Furini, A., Ed.; Springer: Dordrecht, The Netherlands, 2012; pp. 75-86.

5. Yapiyev, V.; Sagintayev, Z.; Inglezakis, V.J.; Samarkhanov, K.; Verhoef, A. Essesntials of endorheic basins and lakes: A review in the context of current and future water resource management and mitigation activities in Central Asia. Water 2017, 9, 798. [CrossRef]

6. García, M.E.; Bundschuh, J.; Ramos, O.; Quintanilla, J.; Persson, K.M.; Bengtsson, L.; Berndtsson, R. Heavy metals in aquatic plans and their relationship to concentrations in surface water, groundwater and sediments-A case study of Poopó basin, Bolivia. Revista Boliviana de Química 2005, 22, 11-18.

7. Clark, A.H.; Farrar, E.; Kontak, D.J.; Langridge, R.J.; Arenas, M.J.; France, L.J.; McBride, S.L.; Woodman, P.L.; Wasteneys, H.A.; Sandeman, H.A.; et al. Geologic and geochronological constrains on the metallogenic evolution of the Andes of southeastern Peru. Econ. Geol. 1990, 85, 1520-1583. [CrossRef]

8. Forturbel, F.E.; Barbieri, E.; Herbas, C.; Barbieri, F.L.; Gardon, J. Indoor metallic pollution related to mining activity in the Bolivian Altiplano. Environ. Pollut. 2011, 159, 280-2875. [CrossRef]

9. Díaz-Barriga, F.; Hamel, J.; Paz, E.; Carrizales, L.; Batres, L.; Calderón, J.; Galvao, L.; Caldas, L.Q.; McConnell, R. Evaluación de Riesgos Para la Salud en la Población Expuesta a Metales en Bolivia; Centro Panamericano de Ecología Humana y Salud: México DF, México, 1997.

10. Mason, H.L. A Flora of the Marshes of California; University of California Press: Berkeley, CA, USA, 1957.

11. Wagner, W.L.; Herbst, D.R.; Sohmer, S.H. Manual of the Flowering Plants of Hawai'i. Vol. 2.; Bishop Museum Special Publication 83; University of Hawai'i; Bishop Museum Press: Honolulu, HI, USA, 1990.

12. Montoya Choque, J.C.; Lovera, P.; Robert, M. Lago Uru Uru: Evaluación de la Calidad del Agua, Sedimentos y Totora; Centro de Ecología y Pueblos Andinos: Oruro, Bolivia, 2009.

13. Hidalgo-Cordero, J.F.; García-Navarro, J. Totora (Schoenoplectus californicus (C.A. Mey.) Soják) and its potential as a construction material. Ind. Crop. Prod. 2018, 112, 467-480. [CrossRef]

14. Vymazal, J. Emergent plants used in free water surface constructed wetlands: A review. Ecol. Eng. 2013, 61, 582-592. [CrossRef]

15. Murray-Gulde, C.L.; Huddleston, G.M.; Garber, K.V.; Rodgers, J.H. Contributions of Schoenoplectus californicus in a constructed wetland system receiving copper contaminated waste water. Water Air Soil Pollut. 2005, 163, 355-378. [CrossRef]

16. Nelson, E.A.; Specht, W.L.; Knox, A.S. Metal removal from water discharges by a constructed treatment wetland. Eng. Life Sci. 2006, 6, 26-30. [CrossRef]

17. Alanoca, L.; Amourous, D.; Momperrus, M.; Tessier, E.; Goni, M.; Guyoneaud, R.; Acha, D.; Gassie, C.; Audry, S.; Garcia, M.E.; et al. Diurnal variability and biogeochemical reactivity of mercury species in an extreme high-altitude lake ecosystem of the Bolivian Altiplano. Environ. Sci. Pollut. Res. 2016, 23, 6919-6933. [CrossRef] [PubMed]

18. García, M.E.; Bundschuh, J.; Ramos, O.; Quintanilla, J.; Persson, K.M.; Bengtsson, L.; Berndtsson, R. Heavy Metal Distribution in a Mining Region. A case Study of Lake Poopó, Bolivia. In Proceedings of the 8th Workshop on Physical Processes in Natural Waters, Department of Water Resources Engineering, Lund, Sweden, August 2004; Lund University: Lund, Sweden, 2004; Available online: www.academia.edu/download/45937267/maria1. doc (accessed on 17 December 2018).

19. Alanoca, L. Cycle Biogéochemique du $\mathrm{Hg}$ dans l'Hydrosystème Tropical d'Altitude lac Uru-Uru, Altiplano Bolivien. Ph.D. Thesis, Université Toulouse III Paul Sabatier, Toulouse, France, 2016.

20. Molina, C.I.; Ibañez, C.; Gibon, F.-M. Proceso de biomagnificación de metales pesados en un lago hiperhialino (Poopó, Oruro, Bolivia): Posible riesgo en la salud de consumidores. Ecología en Bolivia 2012, 47, 99-118. 
21. Ramos Ramos, O.W.; Cáceres, L.F.; Ormaechea Muñoz, M.R.; Bhattacharya, P.; Quino, I.; Quintanilla, J.; Sracek, O.; Thunvik, R.; Bundschuh, J.; García, M.E. Sources and behavior of arsenic and trace elements in groundwater and surface water in the Poopó Lake Basin, Bolivian Altiplano. Environ. Earth Sci. 2012, 66, 793-807. [CrossRef]

22. Autoridad Binacional de Lago Titcaca. Estudio de Hidroquímica y Contaminación. Plan Director Global Binacional de Protección - Prevención de Inundaciones y Aprovechamiento de los Recursos del Lago Titicaca, Río Desaguadero, Lago Poopó y Lago Salar de Coipasa (Sistema, T.D.P.S.); Autoridad Binacional de Lago Titcaca: La Paz, Bolivia, 1993.

23. Matejovic, I. Determination of carbon, hydrogen, and nitrogen in soils by automated elemental analysis (dry combustion method). Commun. Soil Sci. Plant Anal. 1993, 24, 2213-2222. [CrossRef]

24. Olowoyo, J.O.; Van Heerden, E.; Fischer, J.L.; Baker, C. Trace metals in soil and leaves of Jacaranda mimosifolia in Tshwane area, South Africa. Atmos. Environ. 2010, 44, 1826-1830. [CrossRef]

25. Zar, J.H. Bioestatistical Analysis, 4th ed.; Prentice Hall: Upper Saddle River, NJ, USA, 1999.

26. Quinn, G.P.; Keough, M.J. Experimental Design and Data Analysis for Biologists; Cambridge University Press: Cambridge, UK, 2002.

27. Juárez, A.; Arribére, M.A.; Arcagni, M.; Williams, N.; Rizzo, A.; Ribeiro Gueara, S. Heavy metals and trace elements in riparian vegetation and macrophytes associated with lacustrine systems in Northern Patagonia Andean Range. Environ. Sci. Pollut. Res. 2016, 23, 17995-18009. [CrossRef]

28. Rodríguez Ayala, S.; Flores, R.; Rodríguez, M.; Andocilla, M. Quantitative determination of heavy metal hyperaccumulation in a macrophyte simple of Schoenoplectus californius from Lago San Pablo, Imbabura-Ecuador. Revista Ciencia 2017, 4, 431-446.

29. Sundberg-Jones, S.E.; Hassan, S.M. Macrophyte sorption and bioconcentration of elements in a pilot constructed wetland for flue gas desulfurization wastewater treatment. Water Air Soil Pollut. 2007, 183, 187-200. [CrossRef]

30. Marschner, H. Mineral. Nutrition of Higher Plants, 2nd ed.; Academic Press: London, UK, 1995.

31. Bringezu, K.; Lichtenberger, O.; Leopold, I.; Neumann, D. Heavy metal tolerance of Silene vulgaris. J. Plant Physiol. 1999, 154, 536-546. [CrossRef]

32. DalCorso, G. Heavy metal toxicity in plants. In Plants and Heavy Metals; Furini, A., Ed.; Springer: Dordrecht, The Netherlands, 2012; pp. 1-25.

33. Christophersen, H.M.; Smith, S.E.; Pope, S.; Smith, F.A. No evidence for competition between arsenate and phosphate for uptake from soil by medic or barley. Environ. Int. 2009, 35, 485-490. [CrossRef]

34. Zhang, J.; Zhao, Q.Z.; Duan, G.L.; Huang, Y.C. Influence of sulphur on arsenic accumulation and metabolism in rice seedlings. Environ. Exp. Bot. 2011, 72, 34-40. [CrossRef]

35. Romero-Freire, A.; Sierra-Aragón, M.; Ortiz-Bernad, I.; Martín-Peinado, J. Toxicity of arsenic in relation to soil properties: Implications to regulatory purposes. J. Soils Sediments 2014, 14, 968-979. [CrossRef]

36. Duquesnoy, I.; Champeau, G.M.; Evray, G.; Ledoigt, G.; Piquet-Pissaloux, A. Enzymatic adaptations to arsenic-induced oxidative stress in Zea mays and genotoxic effect of arsenic in root tips of Vicia faba and Zea mays. C. R. Biol. 2010, 333, 814-824. [CrossRef]

37. Eun, S.O.; Yon, H.S.; Lee, Y. Lead disturbs microtubule organization in the root meristem of Zea mays. Physiol. Plant. 2000, 110, 357-365. [CrossRef]

38. Sharma, P.; Dubey, R.S. Lead toxicity in plants. Braz. J. Plant Physiol. 2005, 17, 35-52. [CrossRef]

39. DalCorso, G.; Farinati, S.; Maistri, S.; Furini, A. How plants cope with cadmium: Staking all on metabolism and gene expression. J. Integr. Plant Biol. 2008, 50, 1268-1280. [CrossRef] [PubMed]

40. Perfus-Barbeoch, L.; Leonhardt, N.; Vavaddeur, A.; Forestier, C. Heavy metal toxicity: Cadmium permeates through calcium channels and disturbs the plant water status. Plant J. 2002, 32, 539-548. [CrossRef] [PubMed]

41. Athar, R.; Ahmad, M. Heavy metal toxicity in legume-microsymbiont system. J. Plant Nutr. 2002, 25, 369-386. [CrossRef]

42. Pillay, S.V.; Rao, V.S.; Rao, K.V.N. Effect of nickel toxicity in Hyptis suareeolens (L.) Poit. and Helianthus annuus L. Indian J. Plant Physiol. 1996, 1, 153-156.

43. Chen, C.; Huang, D.; Liu, J. Functions and toxicity of nickel in plants: Recent advances and future prospects. Clean 2009, 37, 304-313. [CrossRef]

44. Ahmad, M.S.A.; Hussain, M.; Saddiq, R.; Alvi, A.K. Mungbean: A nickel indicator, accumulator or excluder? Bull. Environ. Contam. Toxicol. 2007, 78, 319-324. [CrossRef] [PubMed] 
45. Alam, M.M.; Hayat, S.; Ali, B.; Ahmad, A. Effect of 28- homobrassinolide treatment on nickel toxicity in Brassica juncea. Photosynthetica 2007, 45, 139-142. [CrossRef]

46. Maksymiec, W.; Baszynski, T. The role of $\mathrm{Ca}^{2+}$ ions in modulating changes induced in bean plants by an excess of $\mathrm{Cu}^{2+}$ ions. Chlorophyll fluorescence measurements. Physiol. Plant. 1999, 105, 562-568. [CrossRef]

47. Pätsikkä, E.; Kairavuo, M.; Sersen, F.; Aro, E.-M.; Tyystjärvi, E. Excess copper predisposes photosystem II to photoinhibition in vivo by outcompeting iron and causing decrease in leaf chlorophyll. Plant Physiol. 2002, 129, 1359-1367. [CrossRef] [PubMed]

48. Batty, L.C.; Younger, P.L. Effects of external iron concentration upon seedling growth and uptake of Fe and phosphate by the common reed, Phragmites australis (Cav.) trin ex steudel. Ann. Bot. 2003, 92, 801-806. [CrossRef] [PubMed]

49. Dučic, T.; Polle, A. Transport and detoxification of manganese and copper in plants. Braz. J. Plant Physiol. 2005, 17, 103-112. [CrossRef]

50. Madejczyk, M.S.; Ballatori, N. The iron transporter ferroportin can also function as a manganese exporter. Biochim. Biophys. Acta Biomembr. 2012, 1818, 651-657. [CrossRef]

51. Zuo, Y.; Zhang, F. Soil and crop management strategies to prevent iron deficiency in crops. Plant Soil 2011, 339, 83-95. [CrossRef]

52. Broadley, M.R.; White, P.J.; Hammond, J.P.; Zelko, I.; Lux, A. Zinc in plants. New Phytol. 2007, 173, $677-702$. [CrossRef]

53. Van Assche, F.; Clijsters, H. Inhibition of photosynthesis in Phaseolus vulgaris by treatment with toxic concentrations of zinc: Effects on electron transport and photo-phosphorylation. Physiol. Plant. 1986, 66, 717-721. [CrossRef]

54. Kaplan, D.I.; Adriano, D.C.; Sajwan, K.S. Thallium toxicity in bean. J. Environ. Qual. 1990, 19, 359-365. [CrossRef]

55. Durrant, P.J.; Durrant, B. Introduction to Advanced Inorganic Chemistry; Longman: London, UK, 1970.

56. Babula, P.; Adam, V.; Opatrilova, R.; Zehnalek, J.; Havel, L.; Kizek, R. Uncommon heavy metals, metalloids and their plant toxicity: A review. Environ. Chem. Lett. 2008, 6, 189-213. [CrossRef]

57. Dumon, J.C.; Erns, W.H.O. Titanium in plants. J. Plant. Physiol. 1988, 133, 203-209. [CrossRef]

58. Kaplan, D.I.; Adriano, D.C.; Carlson, C.L.; Sajwan, S. Vanadium toxicity an accumulation by beans. Water Air Soil Pollut. 1990, 49, 81-91. [CrossRef]

59. McGrath, S.P.; Micó, C.; Curdy, R.; Zhao, F.J. Predicting molybdenum toxicity to higher plants: Influence of soil properties. Environ. Pollut. 2010, 158, 3095-3102. [CrossRef]

60. Isermann, K. Uptake of Stable Strontium by Plants and Effects on Plant Growth. In Handbook of Stable Strontium; Skoryna, S.C., Ed.; Springer: Boston, MA, USA, 1981; pp. 65-86.

61. Terry, N.; Zayed, A.M.; De Souza, M.P.; Tarun, A.S. Selenium in higher plants. Annu. Rev. Plant Physiol. Plant Mol. Biol. 2000, 51, 401-432. [CrossRef]

62. Manara, A. Plant responses to heavy metal toxicity. In Plants and Heavy Metals; Furini, A., Ed.; Springer: Dordrecth, The Netherlands, 2012.

63. Jan, S.; Parray, J.A. Approaches to Heavy Metal Tolerance in Plants; Springer: Singapore, 2016.

64. Gallego, S.M.; Pena, L.B.; Barcia, R.A.; Azpilicueta, C.E.; Iannone, M.F.; Rosales, E.P.; Zawoznik, M.S.; Groppa, M.D.; Benavides, M.P. Unravelling cadmium toxicity and tolerance in plants: Insight into regulatory mechanisms. Environ. Exp. Bot. 2012, 83, 33-46. [CrossRef]

65. Dorman, L.; Castle, J.W.; Rodgers, J.H. Performance of a pilot-scale constructed wetland system for treating simulated ash basin water. Chemosphere 2009, 75, 939-947. [CrossRef]

66. Marchand, L.; Mench, M.; Jacob, D.L.; Otte, M.L. Metal and metalloid removal in constructed wetlands, with emphasis on the importance of plants and standardized measurements: A review. Environ. Pollut. 2010, 158, 3447-3461. [CrossRef]

67. García, M.E.; Bengtsson, L.; Persson, K.M. On the distribution of saline groundwater in the Poopó Basic, central Bolivian highland. Vatten 2005, 66, 199-203.

68. Miller, J.R.; Hudson-Edwards, K.A.; Lechler, P.J.; Preston, D.; Macklin, M.G. Heavy metal contamination of water, soil and produce within riverine communities of the Rio Pilcomayo basin, Bolivia. Sci. Total Environ. 2004, 320, 189-209. [CrossRef] [PubMed] 
69. Smolders, A.J.; Lock, R.A.; Van der Velde, G.; Medina-Hoyos, R.I.; Roelofs, J.G. Effects of mining activities on heavy metal concentrations in water, sediment, and macroinvertebrates in different reaches of the Pilcomayo River, South America. Arch. Environ. Contam. Toxicol. 2003, 44, 314-323. [CrossRef] [PubMed]

70. Reif, J.S.; Ameghino, E.; Aaronson, M.J. Chronic exposure of sheep to a zinc smelter in Peru. Environ. Res. 1989, 49, 40-49. [CrossRef]

71. Fasani, E. Plants that hyperaccumulate heavy metals. In Plants and Heavy Metals; Furini, A., Ed.; Springer: Dordrecht, The Netherlands, 2012; pp. 55-74.

72. Baker, A.J.M.; McGrath, S.P.; Reeves, R.D.; Smith, J.A.C. Chapter 5. Metal hyperaccumulator plants: A review of the ecology and physiology of a biological resource for phytoremediation of metal-polluted soils. In Phytoremediation of Contaminated Soil and Water; Terry, N., Bañuelos, G., Eds.; CRC Press LLC: Boca Raton, FL, USA, 2000.

73. Pillco Zolá, R.; Bengtsson, L. Long-term and extreme water level variations of the shallow Lake Poopó, Bolivia. Hydrol. Sci. J. 2006, 31, 98-114. [CrossRef]

74. Abarca-Del-Río, R.; Crétaux, J.F.; Berge-Nguyen, M.; Maisongrande, P. Does Lake Titicaca still control the Lake Poopó system water levels? An investigation using satellite altimetry and MODIS data (2000-2009). Remote Sens. Lett. 2012, 3, 707-714. [CrossRef]

75. Villamar, C.A.; Neubauer, M.E.; Vidal, G. Distribution and availability of copper and zinc in a constructed wetland fed with treated swine slurry from an anaerobic lagoon. Wetlands 2014, 34, 583-591. [CrossRef]

76. Constantini, M.L.; Sabetta, L.; Mancinelli, G.; Rossi, L. Spatial variability of the decomposition rate of Schoenoplectus tatora in a polluted area of Lake Titicaca. J. Trop. Ecol. 2004, 20, 325-335. [CrossRef]

77. Vyrmazal, J. The use of constructed wetlands for treatment of industrial waste water: A review. Ecol. Eng. 2014, 73, 724-751. [CrossRef]

78. Liang, Y.; Zhu, H.; Bañuelos, G.; Yan, B.; Zhou, Q.; Yu, X.; Cheng, X. Constructed wetlands for saline wastewater treatment: A reivew. Ecol. Eng. 2017, 98, 275-285. [CrossRef]

(C) 2018 by the author. Licensee MDPI, Basel, Switzerland. This article is an open access article distributed under the terms and conditions of the Creative Commons Attribution (CC BY) license (http:/ / creativecommons.org/licenses/by/4.0/). 